\title{
Characteristics of Air Pollutants and Greenhouse Gases at a Regional Background Station in Southwestern China
}

\author{
Linjun Cheng ${ }^{1}$, Dongsheng $\mathrm{Ji}^{2,3 *}$, Jun $\mathrm{He}^{4}$, Liang $\mathrm{Li}^{1}$, Li $\mathrm{Du}^{1}$, Yang $\mathrm{Cui}^{2,5}$, Hongliang $\mathrm{Zhang}^{6}$, \\ Luxi Zhou ${ }^{7}$, Zhiqing Li ${ }^{8}$, Yingxin Zhou', Shengyuan Miao', Zhengyu Gong ${ }^{1}$, Yuesi Wang,3
}

${ }^{1}$ China National Environmental Monitoring Center, Beijing 100012, China

${ }^{2}$ State Key Laboratory of Atmospheric Boundary Layer Physics and Atmospheric Chemistry, Institute of Atmospheric Physics, Chinese Academy of Sciences, Beijing 100191, China

${ }^{3}$ Center for Excellence in Regional Atmospheric Environment, Institute of Urban Environment, Chinese Academy of Sciences, Xiamen 361021, China

${ }^{4}$ International Doctoral Innovation Centre, Department of Chemical and Environmental Engineering, University of Nottingham Ningbo China, Ningbo 315100, China

${ }^{5}$ University of Chinese Academy of Sciences, Beijing 100049, China

${ }^{6}$ Department of Civil \& Environmental Engineering, Louisiana State University, Baton Rouge, Louisiana 70803, USA

${ }^{7}$ National Academies of Sciences, Engineering, and Medicine, Washington, DC 20001, USA

${ }^{8}$ Key Laboratory of Shale Gas and Geoengineering, Institute of Geology and Geophysics, Chinese Academy of Sciences, Beijing 100029, China

${ }^{9}$ Yunnan Wuyi Expressway Construction Headquarters, Yunnan, Kunming 650300, China

\begin{abstract}
The characteristics of air pollutants and greenhouse gases at regional background sites are critical to assessing the impact of anthropogenic emissions on the atmospheric environment, ecosystems and climate change. However, observational studies are still scarce at such background sites. In this study, continuous hourly observations of air pollutants $\left(\mathrm{O}_{3}, \mathrm{CO}, \mathrm{SO}_{2}, \mathrm{NO}_{\mathrm{x}}, \mathrm{PM}_{2.5}\right.$ and $\left.\mathrm{PM}_{10}\right)$ and greenhouse gases $\left(\mathrm{CO}_{2}, \mathrm{CH}_{4}\right.$ and $\left.\mathrm{N}_{2} \mathrm{O}\right)$ were performed for one year (from January 1 to December 31, 2017) at the Gongga Mountain background station (GGS; $101^{\circ} 97^{\prime} \mathrm{E}, 2^{\circ} 9^{\circ} 55^{\prime} \mathrm{N}$; elevation: $3541 \mathrm{~m}$ ) in southwestern China. The concentrations and variations of these air pollutants and greenhouse gases were determined, and the effect of transboundary atmospheric transport on the air pollution at the study site was investigated. The results showed that the average annual concentrations (mixing ratios) of the $\mathrm{O}_{3}, \mathrm{CO}, \mathrm{SO}_{2}, \mathrm{NO}_{2}, \mathrm{CO}_{2}, \mathrm{CH}_{4}, \mathrm{~N}_{2} \mathrm{O}, \mathrm{PM}_{2.5}$ and $\mathrm{PM}_{10}$ were $74.7 \pm 22.0 \mu \mathrm{g} \mathrm{m}^{-3}, 0.3 \pm 0.2 \mathrm{mg} \mathrm{m}^{-3}, 0.5 \pm 0.6 \mu \mathrm{g} \mathrm{m}^{-3}, 1.7 \pm 1.3 \mu \mathrm{g} \mathrm{m}^{-3}, 406.1 \pm 9.5 \mathrm{ppm}, 1.941 \pm$ $0.071 \mathrm{ppm}, 324.5 \pm 14.8 \mathrm{ppb}, 6.5 \pm 6.2 \mu \mathrm{g} \mathrm{m}^{-3}$ and $10.6 \pm 11.2 \mu \mathrm{g} \mathrm{m}^{-3}$, respectively. The concentrations (mixing ratios) of the abovementioned substances at the GGS are comparable to those at other background sites in China and around the world. The slight differences among concentrations at different sites may be mainly attributable to the impacts of anthropogenic emissions near the background sites and meteorological conditions. High values of $\mathrm{O}_{3}$ were observed in spring and summer, while $\mathrm{SO}_{2}$ and $\mathrm{PM}_{2.5}$ showed higher concentrations in summer than in autumn. Relatively high $\mathrm{CO}$, $\mathrm{NO}_{2}$ and $\mathrm{PM}_{10}$ values were mostly observed in spring and winter. Relatively low $\mathrm{CO}_{2}$ concentrations were observed in summer due to the vigorous summertime photosynthesis of vegetation. The lowest concentrations for $\mathrm{CH}_{4} \mathrm{were}$ recorded in summer, whereas the levels in the other three seasons were similar to each other; by contrast, the highest $\mathrm{N}_{2} \mathrm{O}$ concentrations were observed in summer due to enhanced microbial activity resulting from high ambient summer temperatures. A diurnal variation in $\mathrm{O}_{3}$ was observed, with early morning minima and afternoon maxima. $\mathrm{CO}$ and $\mathrm{NO}_{2}$ displayed higher concentrations in the daytime than in the nighttime. A slight increase in both $\mathrm{PM}_{2.5}$ and $\mathrm{PM}_{10}$ concentrations was also recorded in the daytime. These patterns were closely related to scattered anthropogenic emissions and regional atmospheric transport. Nevertheless, $\mathrm{CO}_{2}$ exhibited lower concentrations in the daytime than in the nighttime, although $\mathrm{CH}_{4}$ showed no obvious diurnal variation. The $\mathrm{N}_{2} \mathrm{O}$ concentration peaked between 10:00 and 12:00 (local time), which can be ascribed to the enhancement of microbial activity due to the increased soil temperature. The results based on the relationship between the wind and the concentrations of air pollutants and greenhouse gases were almost consistent with those based on the potential contribution source function. It appears that $\mathrm{O}_{3}$ and its precursors in parts of Inner
\end{abstract}

\footnotetext{
${ }^{*}$ Corresponding author.

E-mail address: jds@mail.iap.ac.cn
} 
Mongolia and Gansu, Ningxia, Sichuan, Chongqing and Hubei Provinces as well as adjacent areas of Hunan, Guizhou and Guangxi Provinces contributed to the increase in $\mathrm{O}_{3}$ at the study site. The potential source areas for $\mathrm{CO}$ and $\mathrm{SO}_{2}$ were similar and mainly distributed in India and Pakistan and areas of Inner Mongolia and Gansu and Guizhou Provinces in China. Potential source areas for $\mathrm{NO}_{2}, \mathrm{PM}_{2.5}$ and $\mathrm{PM}_{10}$ were found in neighboring countries of South Asia in addition to domestic regions, including Inner Mongolia, Gansu Province and the Cheng-Yu economic region. Furthermore, parts of Yunnan Province (China) as well as India and Pakistan were potential source areas for $\mathrm{CO}_{2}, \mathrm{CH}_{4}$ and $\mathrm{N}_{2} \mathrm{O}$.

Keywords: Air pollutants; Greenhouse gases; Background station; Southwestern China.

\section{INTRODUCTION}

Increased occurrence levels of air pollutants (ozone $\left(\mathrm{O}_{3}\right)$, carbon monoxide $(\mathrm{CO})$, sulfur dioxide $\left(\mathrm{SO}_{2}\right)$, nitrogen oxides $\left(\mathrm{NO}_{\mathrm{x}}\right)$, particulate matter with a diameter of 2.5 micrometers or less $\left(\mathrm{PM}_{2.5}\right)$ and particulate matter with a diameter of 10 micrometers or less $\left.\left(\mathrm{PM}_{10}\right)\right)$ and greenhouse gases (carbon dioxide $\left(\mathrm{CO}_{2}\right)$, methane $\left(\mathrm{CH}_{4}\right)$ and nitrous oxide $\left.\left(\mathrm{N}_{2} \mathrm{O}\right)\right)$ caused by intensified anthropogenic emissions have adversely affected the atmospheric environment, ecosystems, climate change and human health (Orru et al., 2017; Wuebbles et al., 2017). Hence, there have been increasing concerns about air pollutants and greenhouse gases at local, regional and even global scales (Meng et al., 2009; Lin et al., 2011; Thunis et al., 2016). Ground-level $\mathrm{O}_{3}$ is a powerful oxidant that can harm lung function and irritate the respiratory system; $\mathrm{O}_{3}$ is also linked to premature deaths, heart attacks and other cardiopulmonary problems (www.epa.gov/ozone-pollution-and-your-patients-health; Weinhold, 2008). In addition, $\mathrm{O}_{3}$ acts as a greenhouse gas (IPCC, 2001). As a precursor of $\mathrm{O}_{3}, \mathrm{CO}$ influences the oxidization of the atmosphere via interactions with hydroxyl radical (OH) (Gligorovski et al., 2015). Frequent occurrences of acid rain and smog are regional-scale environmental problems in China, and $\mathrm{SO}_{2}$ and $\mathrm{NO}_{x}$ play important roles in the formation of both problems (Ji et al., 2014; Seinfeld and Pandis, 2016). Additionally, $\mathrm{NO}_{\mathrm{x}}$ is a photochemical precursor resulting in the substantial enhancement of global background $\mathrm{O}_{3}$ concentrations ( $\mathrm{Lin}$ et al., 2014; Sun et al., 2016). $\mathrm{CO}_{2}, \mathrm{CH}_{4}$ and $\mathrm{N}_{2} \mathrm{O}$ are the most important greenhouse gases (Watson et al., 1992) that can absorb infrared radiation emitted from the earth and partially reradiate this radiation back to the earth's surface (Seinfeld and Pandis, 2016). Therefore, to assess the impact of anthropogenic activities on the atmospheric environment, ecosystems, climate change and human health, it is necessary to conduct long-term continuous measurements of air pollutants $\left(\mathrm{O}_{3}, \mathrm{CO}, \mathrm{SO}_{2}, \mathrm{NO}_{\mathrm{x}}, \mathrm{PM}_{2.5}\right.$ and $\left.\mathrm{PM}_{10}\right)$ and greenhouse gases $\left(\mathrm{CO}_{2}, \mathrm{CH}_{4}\right.$ and $\left.\mathrm{N}_{2} \mathrm{O}\right)$. Nonetheless, colocated and simultaneous measurements of air pollutants and greenhouse gases at regional background sites are scarce, although a series of studies have been performed in regions with high anthropogenic emissions.

In contrast to studies in urban areas, studies on air pollutants and greenhouse gases at regional background sites not only provide valuable information on the influence of human activities on the atmospheric environment and global change but also are helpful for understanding the transboundary transport of air pollution at a regional scale. Regional background sites are affected by very limited local anthropogenic emissions; consequently, the mediumor long-range transport of air pollutants could be the main contributor to local air pollution. Therefore, given their critical importance, a number of studies on air pollutants and greenhouse gases have been carried out at several regional background sites of the Beijing-Tianjin-Hebei (BTH), Yangtze River Delta (YRD) and Pearl River Delta (PRD) regions in China (Chao et al., 2014; Pu et al., 2015; Wang et al., 2016). The results of these studies reflected the distinctive air pollution characteristics in the abovementioned regions in China and showed significant impacts of human activities on regional air quality. However, such studies at regional background sites in southwestern China are still scarce. The Gongga Mountain background station (GGS) is representative of the regional background in southwestern China (Fu et al., 2008; Zhang et al., 2012; Zhang et al., 2014; Li et al., 2017). Several field observations have been conducted at this station on volatile organic compounds, polar organic tracers in $\mathrm{PM}_{2.5}$ and total particulate, reactive gaseous mercury and major chemical species of $\mathrm{PM}_{10}$ in specific periods or months (Fu et al., 2008; Zhang et al., 2012; Zhang et al., 2014; Li et al., 2017). However, to the best of our knowledge, no long-term continuous measurement of air pollutants and greenhouse gases has been performed at any regional background sites in southwestern China.

In this study, we present observations of major air pollutants, including $\mathrm{O}_{3}, \mathrm{CO}, \mathrm{SO}_{2}, \mathrm{NO}_{\mathrm{x}}, \mathrm{PM}_{2.5}$ and $\mathrm{PM}_{10}$, as well as greenhouse gases, such as $\mathrm{CO}_{2}, \mathrm{CH}_{4}$ and $\mathrm{N}_{2} \mathrm{O}$, at the GGS $\left(101^{\circ} 97^{\prime} \mathrm{E}, 29^{\circ} 55^{\prime} \mathrm{N}\right.$; elevation: $\left.3541 \mathrm{~m}\right)$ in southwestern China for the first time. The occurrence levels and temporal variations in these pollutants are discussed in detail, and potential contribution areas of the above substances are identified using the potential source contribution function (PSCF) method.

\section{METHODS AND INSTRUMENTS}

\section{Sampling Site}

As shown in Fig. 1, the GGS $\left(101.97^{\circ} \mathrm{E}, 29.55^{\circ} \mathrm{N}\right.$; elevation: $3541 \mathrm{~m}$ ) was established in the Gongga Mountain Observation and Experimental Station of Alpine Ecosystem, which is located in the Hailuogou scenic area of the southeastern edge of the Qinghai-Tibetan Plateau. The Hailuogou scenic area is famous for its large unique glacier and forest park areas. Neither private vehicular transport nor industrial activities operate near the sampling 

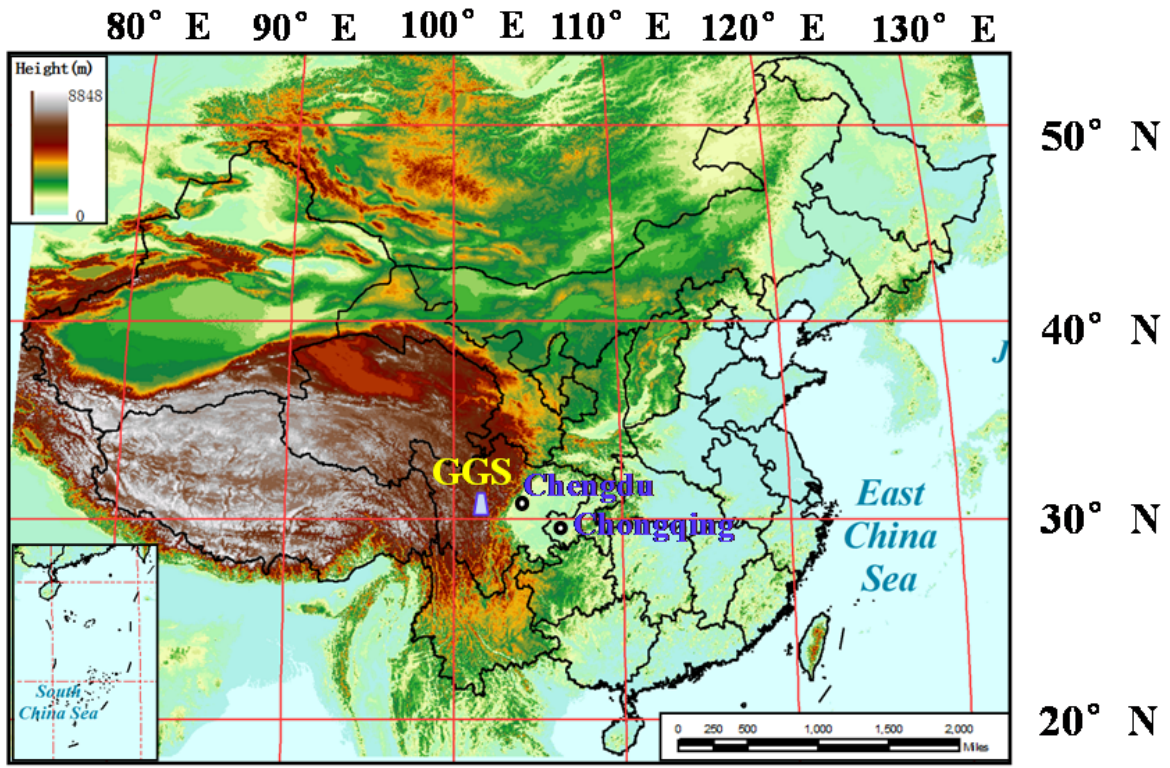

Fig. 1. Location of the GGS atmospheric background station.

site. This station is approximately $250 \mathrm{~km}$ from Chengdu, the capital of Sichuan Province. There are two major roads in the north and east, $500 \mathrm{~m}$ and $400 \mathrm{~m}$ away from the station, respectively. The study area is dominated by the Southeast Asian Monsoon, with an annual average temperature, relative humidity, wind speed, atmospheric pressure and visibility range of $2.1 \pm 6.6^{\circ} \mathrm{C}, 82.5 \pm 20.9 \%$, $1.7 \pm 0.9 \mathrm{~m} \mathrm{~s}^{-1}, 656.5 \pm 25.0 \mathrm{hPa}$ and $21.7 \pm 24.8 \mathrm{~km}$, respectively. In addition, higher precipitation mainly occurs in both summer and autumn.

\section{Instruments and Measurement Data}

The sampling campaign was conducted from January 1, 2017, to December 31, 2017. All instruments were deployed, operated and maintained by following the regulations and standard operating procedures defined by the Ministry of Ecology and Environment of the People's Republic of China (http://bz.mep.gov.cn/bzwb/dqhjbh/jcgfffbz/index 2 . shtml). The precision, detection limits, and calibration methods of all analyzers/monitors for major air pollutants of interest, including $\mathrm{O}_{3}, \mathrm{CO}, \mathrm{SO}_{2}, \mathrm{NO}_{\mathrm{x}}, \mathrm{CO}_{2}, \mathrm{CH}_{4}, \mathrm{~N}_{2} \mathrm{O}$, $\mathrm{PM}_{2.5}$ and $\mathrm{PM}_{10}$, have been described elsewhere in detail (Ji et al., 2014; Christiansen et al., 2015; Cortus et al., 2015). Briefly, $\mathrm{O}_{3}, \mathrm{CO}, \mathrm{SO}_{2}, \mathrm{NO}-\mathrm{NO}_{2}-\mathrm{NO}_{\mathrm{x}}, \mathrm{CO}_{2}, \mathrm{CH}_{4}$ and $\mathrm{N}_{2} \mathrm{O}$ were observed using an ultraviolet photometric analyzer (Model 49i; Thermo Fisher Scientific (Thermo), USA), a gas filter correlation nondispersive infrared method analyzer (Model 48i TLE; Thermo, USA), a pulsedfluorescence analyzer (Model 43i-TLE; Thermo, USA), a chemiluminescence analyzer (Model 42i-TL; Thermo, USA), a cavity ring-down spectroscopy analyzer for $\mathrm{CO}_{2}$ and $\mathrm{CH}_{4}$ (Model G2301; Picarro, Inc., USA) and a gas filter correlation $\mathrm{N}_{2} \mathrm{O}$ analyzer (Model 320EU; Teledyne Technologies, USA), respectively. $\mathrm{PM}_{2.5}$ and $\mathrm{PM}_{10}$ were simultaneously monitored using a Tapered Element Oscillating Microbalance with a Filter Dynamics Measurement System (TEOM-FDMS; 1405-DF TEOM; Thermo, USA). The gases were calibrated daily by injecting a mixture of calibration gases (ScottMarrin, Inc., CA, USA) and scrubbed ambient air. In addition, an internal catalytic converter was used to calibrate the $\mathrm{CO}$ blank. The TEOM-FDMS was calibrated with free-particle and standard filters (Thermo, USA). Meteorological parameters such as relative humidity $(\mathrm{RH})$, wind direction (WD), wind speed (WS) and atmospheric temperature (T) were recorded via a colocated automatic meteorological station (Model AWS310; Vaisala, Finland). All data were processed using an Igor-based software (Wu et al., 2018).

\section{Source Area Identification}

The PSCF method has been extensively used in identifying source locations of atmospheric species (Lupu and Maenhaut, 2002). PSCF is defined as the probability that an air parcel with a concentration more than a specified threshold reaches the study site after having resided in a certain grid cell of the spatial domain of interest (Lupu and Maenhaut, 2002). In this study, the potential source areas are identified based on the PSCF method using a GIS-based tool, named Trajstat, which can perform a comprehensive investigation of the geographical distribution of atmospheric species origins (Wang et al., 2009).

\section{RESULTS AND DISCUSSION}

\section{Occurrence Levels}

The time series of $\mathrm{O}_{3}, \mathrm{CO}, \mathrm{SO}_{2}, \mathrm{NO}, \mathrm{NO}_{2}, \mathrm{PM}_{2.5}$ and $\mathrm{PM}_{10}$ concentrations as well as $\mathrm{CO}_{2}, \mathrm{CH}_{4}$ and $\mathrm{N}_{2} \mathrm{O}$ mixing ratios are presented from January 1 to December 31, 2017, in Fig. 2. In addition, the means and standard deviations (STDEVs) of air pollutants and greenhouse gases are listed in Table 1. For clarification, due to regular maintenance activities (e.g., periodic zero-span checks, data dump/ collection, calibrations, etc.) and disruptions by severe weather conditions, a number of datasets were not recorded during the above sampling period. The annual average 

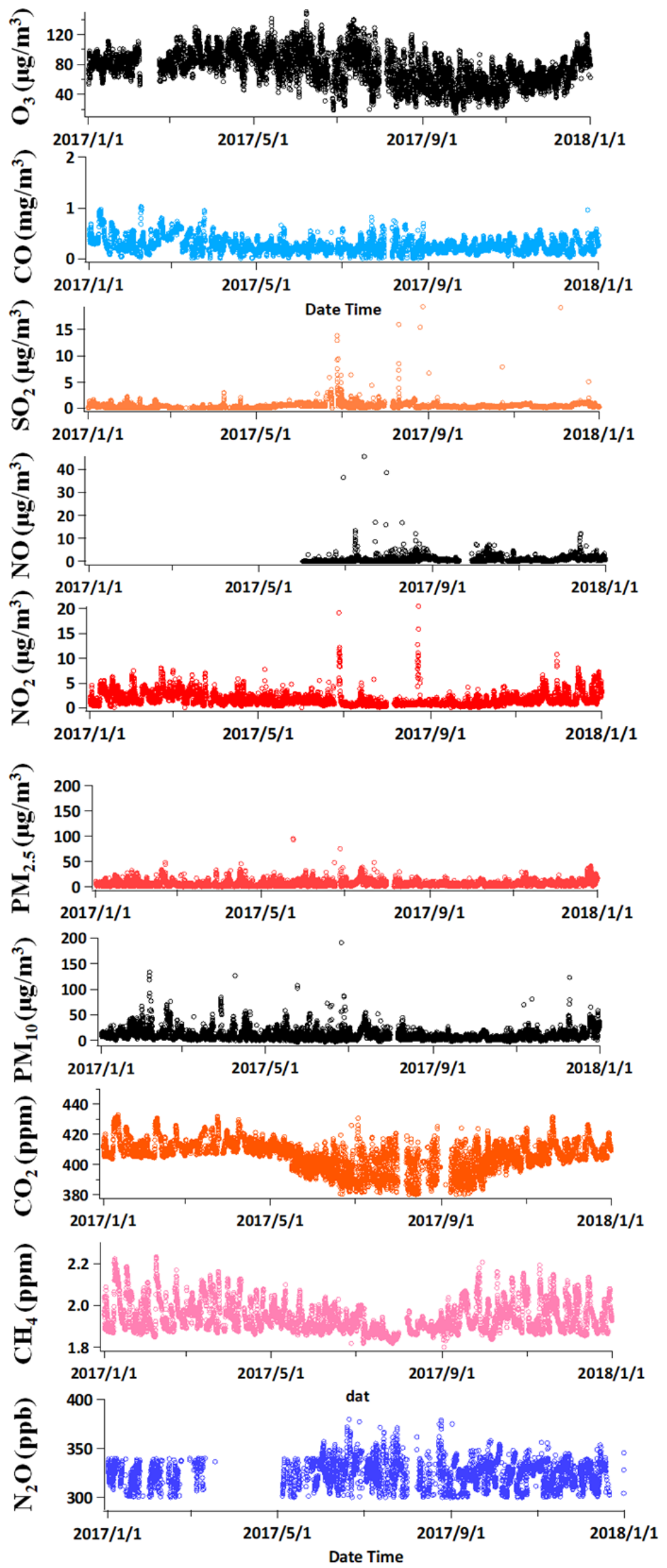

Fig. 2. Time series of $\mathrm{O}_{3}, \mathrm{CO}, \mathrm{SO}_{2}, \mathrm{NO}_{x}, \mathrm{CO}_{2}, \mathrm{CH}_{4}, \mathrm{~N}_{2} \mathrm{O}, \mathrm{PM}_{2.5}$ and $\mathrm{PM}_{10}$ concentrations and mixing ratios in 2017. 


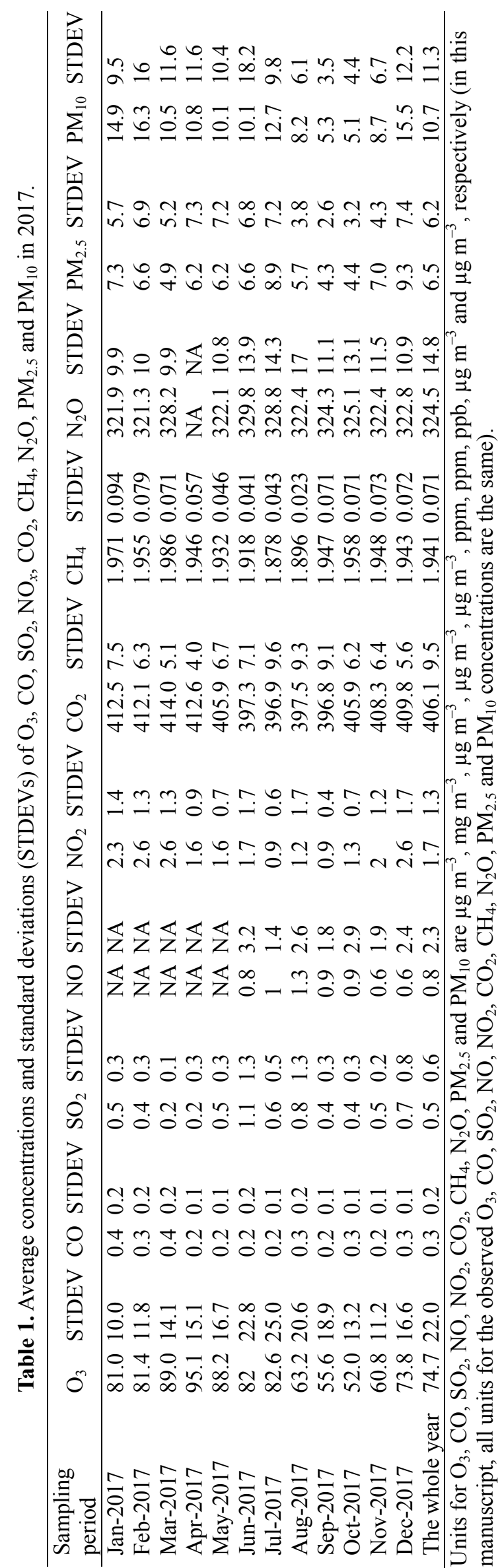

concentrations (mixing ratios) of $\mathrm{O}_{3}, \mathrm{CO}, \mathrm{SO}_{2}, \mathrm{NO}, \mathrm{NO}_{2}$, $\mathrm{PM}_{2.5}$, and $\mathrm{PM}_{10}$ as well as $\mathrm{CO}_{2}, \mathrm{CH}_{4}$ and $\mathrm{N}_{2} \mathrm{O}$ were $74.7 \pm$ $22.0 \mu \mathrm{g} \mathrm{m}^{-3}, 0.3 \pm 0.2 \mathrm{mg} \mathrm{m}^{-3}, 0.5 \pm 0.6 \mu \mathrm{g} \mathrm{m}^{-3}, 0.8 \pm$ $2.3 \mu \mathrm{g} \mathrm{m}^{-3}, 1.7 \pm 1.3 \mu \mathrm{g} \mathrm{m}^{-3}, 6.5 \pm 6.2 \mu \mathrm{g} \mathrm{m}^{-3}, 10.6 \pm$ $11.2 \mu \mathrm{g} \mathrm{m}^{-3}, 406.1 \pm 9.5 \mathrm{ppm}, 1.941 \pm 0.071 \mathrm{ppm}$ and $324.5 \pm 14.8 \mathrm{ppb}$, respectively. According to the Chinese Ambient Air Quality Tier II Standards (CAAQS), there were no sampling days when the thresholds of $\mathrm{O}_{3}$ (maximum $8 \mathrm{~h}$ mean: $\left.160 \mu \mathrm{g} \mathrm{m}^{-3}\right), \mathrm{NO}_{2}\left(24 \mathrm{~h}\right.$ mean: $\left.80 \mu \mathrm{g} \mathrm{m}^{-3}\right), \mathrm{SO}_{2}$ (24 h mean: $\left.150 \mu \mathrm{g} \mathrm{m}^{-3}\right)$, CO $\left(24 \mathrm{~h}\right.$ mean: $\left.4 \mathrm{mg} \mathrm{m}^{-3}\right)$, $\mathrm{PM}_{2.5}\left(24 \mathrm{~h}\right.$ mean: $\left.75 \mu \mathrm{g} \mathrm{m}^{-3}\right)$ and $\mathrm{PM}_{10}(24 \mathrm{~h}$ mean: $150 \mu \mathrm{g} \mathrm{m}^{-3}$ ) were exceeded. However, there were 82,1 and 1 days violating the limits of $\mathrm{O}_{3}$ (maximum $8 \mathrm{~h}$ mean: $\left.100 \mu \mathrm{g} \mathrm{m}^{-3}\right), \mathrm{PM}_{2.5}\left(24 \mathrm{~h}\right.$ mean: $\left.25 \mu \mathrm{g} \mathrm{m}^{-3}\right)$ and $\mathrm{PM}_{10}(24 \mathrm{~h}$ mean: $50 \mu \mathrm{g} \mathrm{m}^{-3}$ ), respectively, according to the World Health Organization (WHO) air quality standards. Notably, $54.9 \%$ of all days exceeded the WHO ozone standard in the spring, which is consistent with the spring $\mathrm{O}_{3}$ maximum observed in the Northern Hemisphere (Monks, 2000; Lin et al., 2015). In addition, the sampling days exceeding the WHO PM standards were closely related to the long-range transport of PM from regions of intense anthropogenic emissions and/or local emissions.

Frequency distributions are a commonly used visualization tool used to display the number of observations within a given interval. In this study, histograms showing the normalized, lognormal and cumulative frequency distributions of $\mathrm{O}_{3}, \mathrm{CO}, \mathrm{SO}_{2}, \mathrm{NO}, \mathrm{NO}_{2}, \mathrm{PM}_{2.5}$ and $\mathrm{PM}_{10}$ concentrations and $\mathrm{CO}_{2}, \mathrm{CH}_{4}$ and $\mathrm{N}_{2} \mathrm{O}$ mixing ratios were plotted and are presented in Fig. 3. The results show that all of the air pollutants of interest in this study possessed a unimodal bell-shaped lognormal distribution pattern during the entire sampling period. For example, $\mathrm{O}_{3}$ concentrations ranging from 30 to $130 \mu \mathrm{g} \mathrm{m}^{-3}$ were dominant, and the distribution shape for $\mathrm{O}_{3}$ was generally symmetrical, with the highest frequency at $90 \mu \mathrm{g} \mathrm{m}^{-3}$, occupying more than $95 \%$ of the total sample data. It was reported that the frequency distribution of $\mathrm{O}_{3}$ concentrations can be a good indicator for the studied type of sampling site because this distribution captures the impact of $\mathrm{NO}_{\mathrm{x}}$ emission sources mainly associated with combustion activities (Escudero et $a l ., 2014)$. Based on the diurnal variations in both $\mathrm{O}_{3}$ and NO (Section Seasonal and Diurnal Variations), in such a remote site, NO titration most likely seldom affects the $\mathrm{O}_{3}$ frequency distribution, although other processes, such as deposition or scavenging, might play more important roles in removing $\mathrm{O}_{3}$ from the troposphere (Monks et al., 2015). The frequency distributions of $\mathrm{CO}, \mathrm{SO}_{2}, \mathrm{NO}_{2}, \mathrm{PM}_{2.5}$ and $\mathrm{PM}_{10}$ were more skewed to the right compared with the other distributions and featured a pronounced peak at approximately $0.25 \mathrm{mg} \mathrm{m}^{-3}, 0.22 \mu \mathrm{g} \mathrm{m}^{-3}, 1.0 \mu \mathrm{g} \mathrm{m}^{-3}$, $4 \mu \mathrm{g} \mathrm{m}^{-3}$ and $6 \mu \mathrm{g} \mathrm{m}^{-3}$, respectively, indicating the impact of relatively clean background continental air masses, while the long tails on the right side of the graph toward high concentration levels with a low cumulative distribution could indicate the minor influence of local rural pollution and/or urban pollution plumes. NO concentrations ranging from 0.1 to $1.0 \mu \mathrm{g} \mathrm{m}^{-3}$ were dominant, accounting for approximately $98 \%$ of the total sample data. Although the 

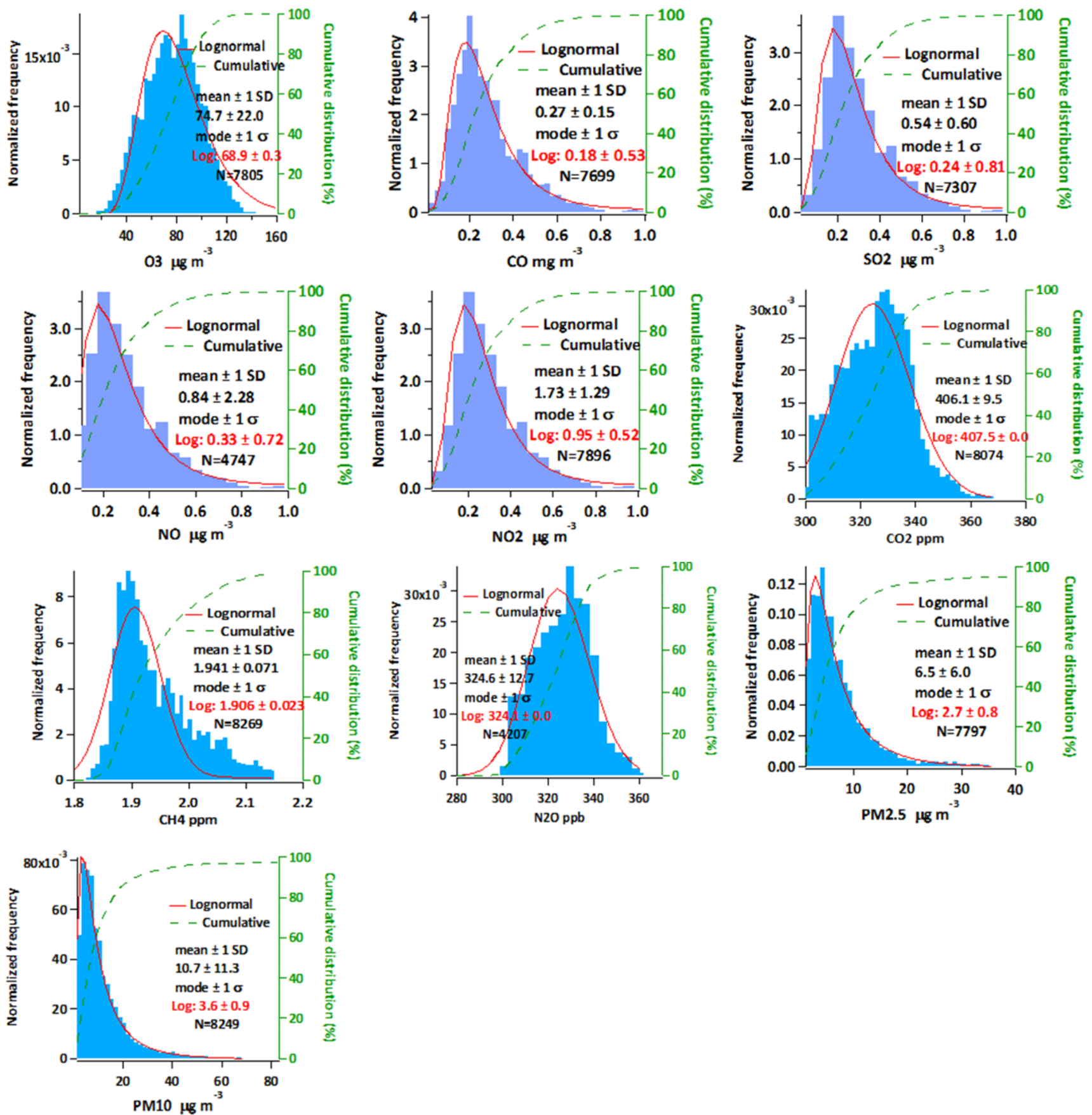

Fig. 3. Frequency distributions of $\mathrm{O}_{3}, \mathrm{CO}, \mathrm{SO}_{2}, \mathrm{NO}, \mathrm{NO}_{2}, \mathrm{CO}_{2}, \mathrm{CH}_{4}, \mathrm{~N}_{2} \mathrm{O}, \mathrm{PM}_{2.5}$ and $\mathrm{PM}_{10}$ concentrations or mixing ratios.

NO dataset was only slightly more than half of that for the remaining pollutants, the right-skewed frequency distribution of NO was similar to the above trend, with a long tail on the right side. In addition, Fig. 3 clearly shows that the frequency distributions of the $\mathrm{CO}_{2}, \mathrm{CH}_{4}$ and $\mathrm{N}_{2} \mathrm{O}$ mixing ratios were very narrow and were in the ranges of 380.1-435.0 ppm, 1.802-2.232 ppm and 300.0-379.9 ppb, respectively; such patterns might indicate that high emissions of these gases had almost no impacts during the study period.

As shown in Table 2, a comparative analysis was conducted between the observations in the present study and those reported earlier at background stations in China and worldwide. The annual mean $\mathrm{O}_{3}$ concentration $(74.7 \pm$ $22.0 \mu \mathrm{g} \mathrm{m}^{-3}$ ) at the GGS was higher than the values observed at the Dinghushan (DHS) background site in southern China (24.6 ppb; Chao et al., 2014), the Jinsha (JS) background station in central China (24.6 ppb; Lin et al., 2011) and the Lin'an (LA) background station in the YRD of China (34.7 ppb; Xu et al., 2008); and it was similar to the values observed at the Shangdianzi (SDZ) background station in the BTH region of China (36.9 ppb; Lin et al., 2008) and the remote highland site of Dangxiong 
$\stackrel{\circ}{\stackrel{2}{*}}$

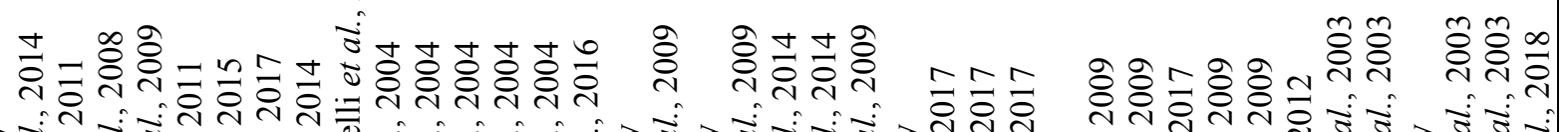

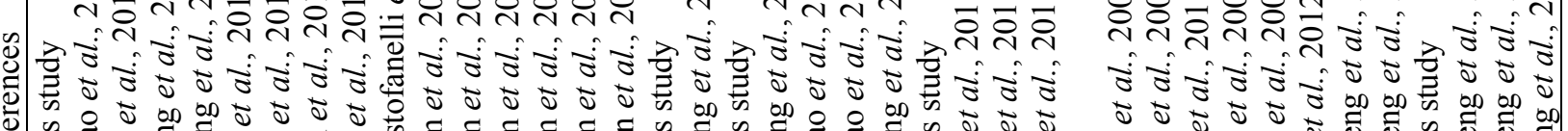

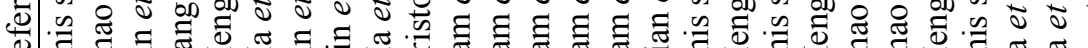

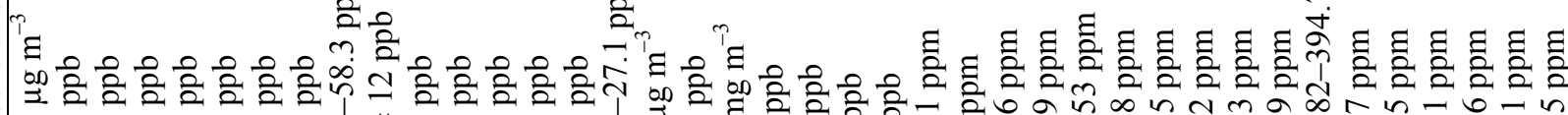

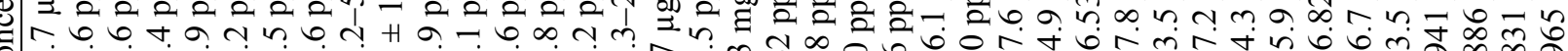
U. (1)

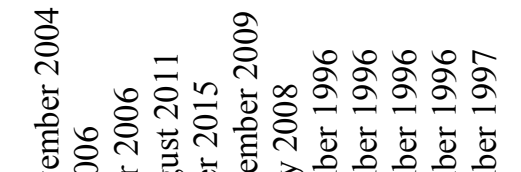

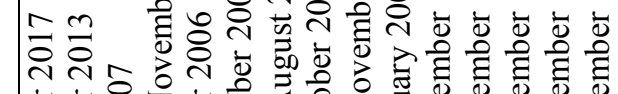

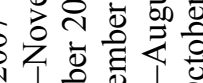

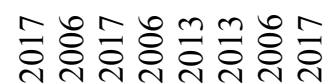

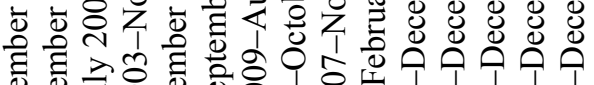

范

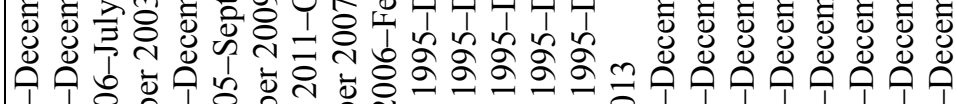

हี है है है है है है

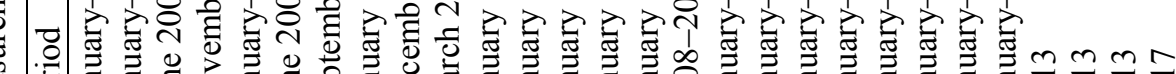

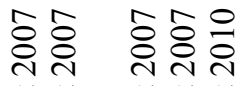

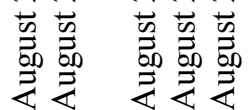

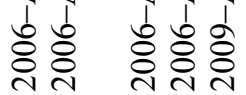

芉

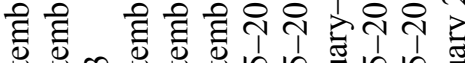
U己

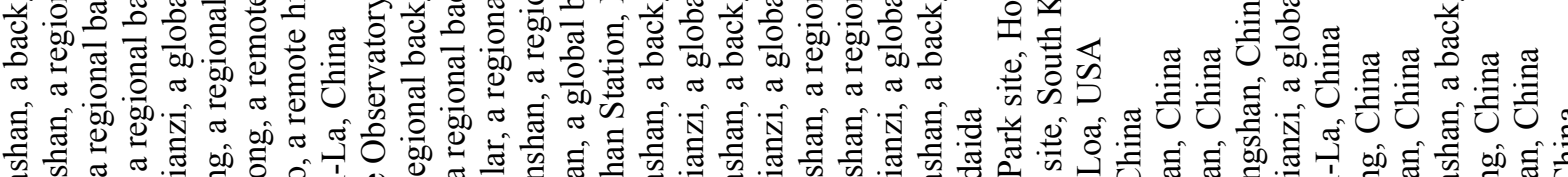

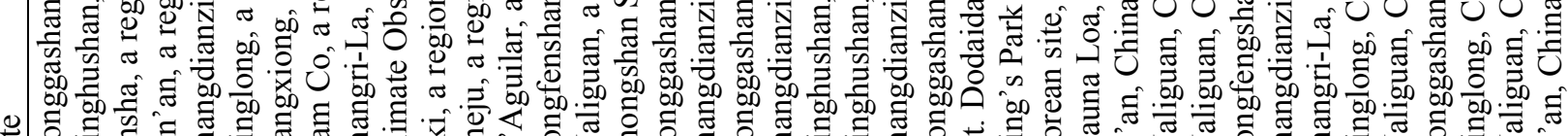

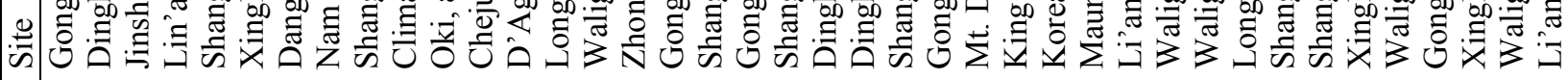




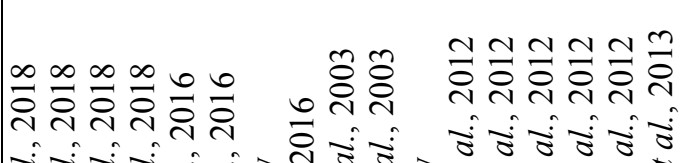
4

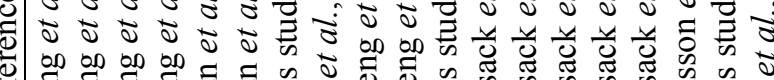

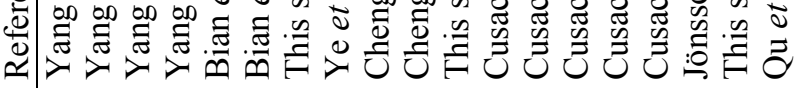

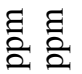

อี

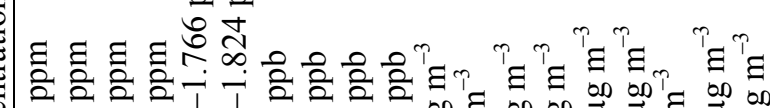
U人+

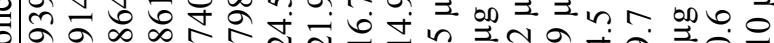

m?

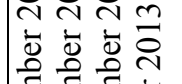

चे है

范苾

oे oे oे

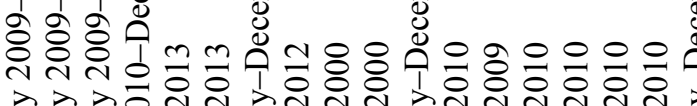

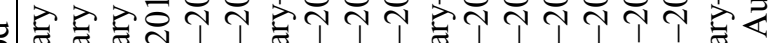

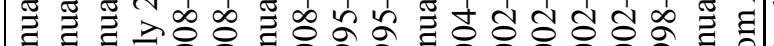

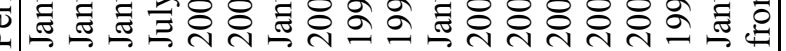

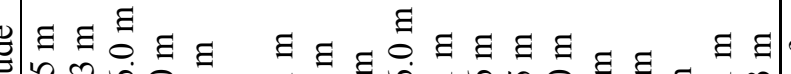

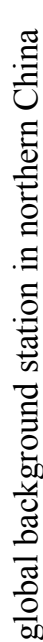

章

(a)

$\because \quad \because \widetilde{\pi}$

垔 
(38.5 ppb; Lin et al., 2015); while it was lower than those observed at Nam Co, a remote highland site in the inland Tibetan Plateau of China (47.6 \pm 11.6 ppb, $4730 \mathrm{~m}$ a.s.1.), the Xinglong background station in northern China (49.2 ppb, $960 \mathrm{~m}$ a.s.1.), and the Nepal Climate Observatory-Pyramid (49 \pm 12 ppbv, 4745 m a.s.l.; Cristofanelli et al., 2010). Given that the GGS site is at a much higher latitude than the other sites, the contribution of stratospheric ozone intrusion at the GGS may be more significant than the stratosphere-totroposphere transport at most of the other stations discussed here (Mauzerall et al., 1996). The concentrations of $\mathrm{NO}_{2}$ at the GGS were lower than those at the DHS, SDZ, and LA sites, which was consistent with the fact that the DHS, SDZ, and LA sites are in rapidly developing areas with much more intensive industrial emissions and a high increase in the number of motor vehicles. In contrast, the concentrations of $\mathrm{SO}_{2}$ and $\mathrm{CO}$ observed at the GGS were lower than those observed at the DHS, SDZ, JS and LA stations, which also indicates the limited influence of anthropogenic activities at the GGS.

The annual mean $\mathrm{CO}_{2}$ concentration $(406.1 \pm 9.5 \mathrm{ppm})$ at the GGS was similar to that at the background sites of Mt. Dodaira, Japan (> 400 ppm in 2013); King's Park, Hong Kong, China (407.6 ppm in 2013); Korea (404.9 ppm in 2013); Mauna Loa (global background site; $406.53 \mathrm{ppm}$ in 2017) and LA $(404.7 \pm 8.2 \mathrm{ppm}, 405.6 \pm 5.3 \mathrm{ppm}$ and $407.0 \pm 5.3 \mathrm{ppm}$ for 2009,2010 and 2011, respectively). However, the annual mean $\mathrm{CO}_{2}$ concentration at the GGS was higher than that observed from September 2006 to August 2007 at the Waliguan (WLG; 383.5 ppm), SDZ (385.9 ppm), LA (387.8 ppm) and Longfengshan (LFS; $384.3 \mathrm{ppm}$ ) background sites. This trend suggests that $\mathrm{CO}_{2}$ concentrations at the abovementioned background sites in China have increased significantly over the past decade, possibly due to the rapid economic development and extensive enhancement of energy consumption (http://www. stats.gov.cn/tjsj/ndsj/2017/indexch.htm). The average $\mathrm{CH}_{4}$ concentrations at the GGS were higher than those observed at the Antarctica site (1.740-1.766 ppm), the WLG background site $(1.864 \mathrm{ppm})$ and the Shangri-La background site $(1.861 \mathrm{ppm})$ as well as the global background concentration (1.798-1.824 ppm) (Bian et al., 2016) but were similar to those at the SDZ (1.914 ppm), LA (1.965 ppm) and LFS $(1.939 \mathrm{ppm})$ background sites. In addition, the monthly average $\mathrm{N}_{2} \mathrm{O}$ concentrations, which ranged from 321.3 to $329.8 \mathrm{ppb}$ in the GGS, were similar to those at Zhongshan Station, East Antarctica, which varied from 320.5 to $324.8 \mathrm{ppb}$ (Ye et al., 2016), but higher than those at the Xinglong $\left(316.7 \times 10^{-9}\right.$, from 1995 to 2000$)$ and WLG (314.9 $\times 10^{-9}$, from 1995 to 2000$)$ background sites.

Compared to the observations at other background sites in the world, the $\mathrm{PM}_{2.5}$ concentrations measured at the GGS site $\left(6.5 \pm 6.2 \mu \mathrm{g} \mathrm{m}^{-3}\right)$ were slightly lower than or similar to those at the Portugal $\left(9.4 \mu \mathrm{g} \mathrm{m}^{-3}\right)$, Germany $\left(10 \mu \mathrm{g} \mathrm{m}^{-3}\right)$ and Scandinavia $\left(6.6 \mu \mathrm{g} \mathrm{m}^{-3}\right)$ background sites and were considerably lower than those recorded at the Switzerland $\left(14.5 \mu \mathrm{g} \mathrm{m}^{-3}\right.$ ) and Austria (19.7 $\mu \mathrm{g} \mathrm{m}^{-3}$ ) background sites. The annual $\mathrm{PM}_{10}$ concentration was almost the same as a previous result $\left(10.8 \mu \mathrm{g} \mathrm{m}^{-3}\right)$ from the
Stockholm regional background site in Europe (Jonsson et al., 2013). Although most background monitoring sites are distant from urban areas, they might be affected by anthropogenic emissions to different extents. In addition, synoptic conditions play an important role in PM levels (Ji et al., 2012); for instance, differences in the precipitation intensity and atmospheric stagnation of various sites could affect the removal, transport and accumulation of particulate matter. Furthermore, the transboundary transport of air masses from regions of intense anthropogenic activities can lead to spatial variation in the levels of air pollutants at various background sites.

Overall, the air quality at the GGS site was better than that at the background sites located in the most populated and developed city clusters, such as the BTH, YRD and PRD regions of China. In addition to meteorological conditions and various sinks, the spatial variation in the levels of air pollutants in different regions could be highly affected by regional emission intensities of major air pollutants of interest (National Bureau of Statistics of the People's Republic of China, 2017).

\section{Seasonal and Diurnal Variations}

The average seasonal variations in $\mathrm{O}_{3}, \mathrm{CO}, \mathrm{SO}_{2}, \mathrm{~N}_{2} \mathrm{O}$, $\mathrm{PM}_{2.5}, \mathrm{PM}_{10}, \mathrm{NO}_{2}, \mathrm{CO}_{2}$ and $\mathrm{CH}_{4}$ and the RH, T and WS values at the GGS are shown in Fig. 4. The highest values of $\mathrm{O}_{3}$ were observed in spring, while the lowest values occurred in autumn. The maximum $\mathrm{O}_{3}$ value in spring is consistent with the spring $\mathrm{O}_{3}$ maximum frequently observed in the Northern Hemisphere (Monks, 2000; Vingarzan, 2004; Ran et al., 2014; Lin et al., 2015). Stronger ultraviolet (UV) radiation has been observed in spring at the GGS (Liu et al., 2017), which was favorable for $\mathrm{O}_{3}$ production and further contributed to the highest $\mathrm{O}_{3}$ concentrations in spring. The lower levels of CO from April to July were almost opposite to the seasonal variation in $\mathrm{O}_{3}$, which could be caused by the yield of $\mathrm{O}_{3}$ from $\mathrm{CO}$ oxidation under stronger UV radiation (Seinfeld and Pandis, 2016). The higher $\mathrm{CO}_{2}$ concentrations observed in April and May might originate from $\mathrm{CO}$ oxidation, which supports the above deduction to a degree. However, vigorous summertime photosynthesis resulted in a decline in $\mathrm{CO}_{2}$ concentrations in the summer. The $\mathrm{O}_{3}$ levels were relatively lower in late summer and autumn compared with those in spring. The high occurrence frequency of precipitation could scavenge more $\mathrm{O}_{3}$ in late summer and autumn than the other two seasons. $\mathrm{SO}_{2}$ and $\mathrm{PM}_{2.5}$ showed the highest concentrations in summer and the lowest concentrations in autumn. As shown in Fig. 2, high concentration spikes of both $\mathrm{SO}_{2}$ and $\mathrm{PM}_{2.5}$ could be observed. Given that the lifetime of $\mathrm{SO}_{2}$ is normally short under conditions of high $\mathrm{RH}$ and $\mathrm{O}_{3}$ concentrations (Seinfeld and Pandis, 2016), it might be reasonable to infer that local emissions outweighed the regional transport of both pollutants, resulting in the increased concentrations of $\mathrm{RH}$ and $\mathrm{O}_{3}$ at this background site. Note that pulse spikes of $\mathrm{SO}_{2}$ and $\mathrm{PM}_{2.5}$ accompanied the increase in $\mathrm{CO}$ and $\mathrm{NO}_{2}$ concentrations. In addition, $\mathrm{PM}_{10}$ did not increase as significantly as $\mathrm{PM}_{2.5}$ during the sampling period. Hence, all these observations could lead 

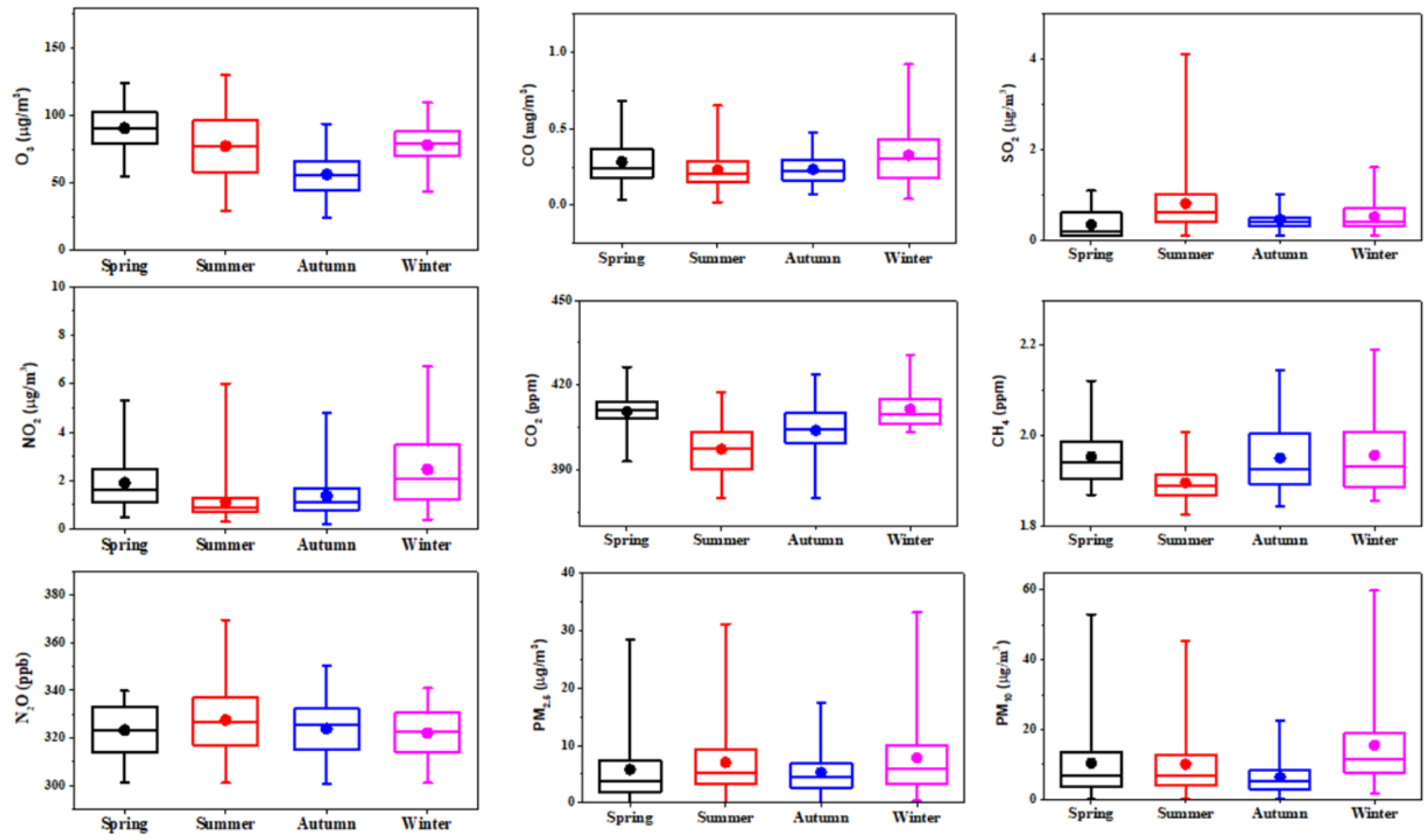

(a)
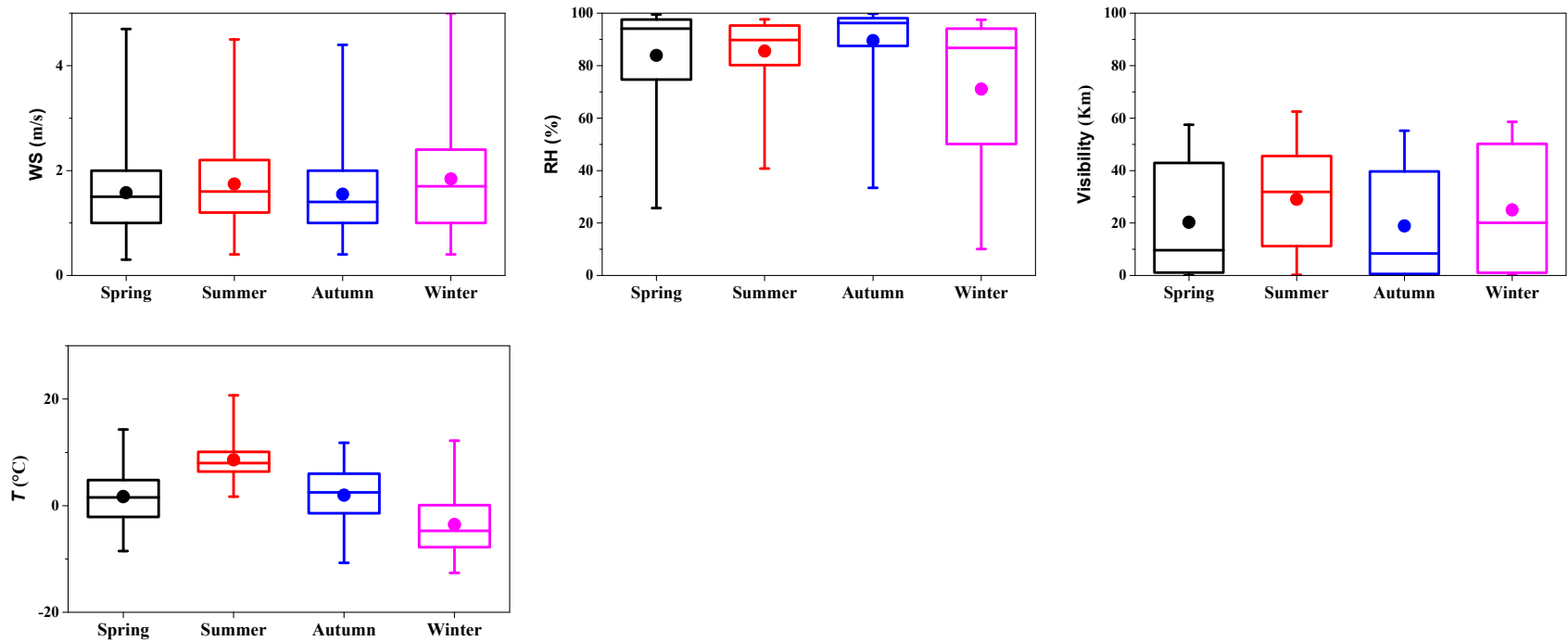

(b)

Fig. 4. The average seasonal variations in $\mathrm{O}_{3}, \mathrm{CO}, \mathrm{SO}_{2}, \mathrm{NO}_{2}, \mathrm{CO}_{2}, \mathrm{CH}_{4}, \mathrm{~N}_{2} \mathrm{O}, \mathrm{PM}_{2.5}$ and $\mathrm{PM}_{10}$ (a) as well as $\mathrm{RH}$, $\mathrm{T}$ and WS; (b) at the GGS.

to the hypothesis that the local air quality at such a remote site might be affected more by traffic emissions during summer than during other seasons. Because the Hailuogou scenic area is most attractive to tourists during summer, this difference could be ascribed to vehicular emissions from tourists. The seasonal pattern of $\mathrm{CO}$ was similar to that of $\mathrm{NO}_{2}$ and $\mathrm{PM}_{10}$. The highest $\mathrm{CO}, \mathrm{NO}_{2}$ and $\mathrm{PM}_{10}$ values were mostly observed in winter. The lowest $\mathrm{CO}_{2}$ concentrations were observed in summer, which could be because vigorous summertime photosynthesis resulted in a decline in $\mathrm{CO}_{2}$ mixing ratios. The lowest $\mathrm{CH}_{4}$ concentrations were recorded in summer, while the $\mathrm{CH}_{4}$ levels in the other three seasons were very similar to each other. Such a seasonality of the $\mathrm{CH}_{4}$ mixing ratio in a clean-background environment is possibly related to $\mathrm{OH}$ radicals that are dependent on the seasonally varying intensity of ultraviolet radiation (Necki et al., 2003). In contrast, higher $\mathrm{N}_{2} \mathrm{O}$ concentrations were observed in summer than during the 
other seasons due to increases in the emission of $\mathrm{N}_{2} \mathrm{O}$ caused by enhanced microbial activity at higher ambient temperatures (Wang et al., 2018).

The average diurnal variations in $\mathrm{O}_{3}, \mathrm{CO}, \mathrm{SO}_{2}, \mathrm{NO}_{\mathrm{x}}$, $\mathrm{CO}_{2}, \mathrm{CH}_{4}, \mathrm{~N}_{2} \mathrm{O}, \mathrm{PM}_{2.5}$ and $\mathrm{PM}_{10}$ as well as meteorological conditions, namely, RH, T and WS, at the GGS are shown in Fig. 5. The diurnal cycles of $\mathrm{O}_{3}$ showed minimum and maximum values in the early morning and afternoon, respectively. During the nighttime, the ozone concentration decreased slowly, mainly due to the titration of $\mathrm{NO}$ and
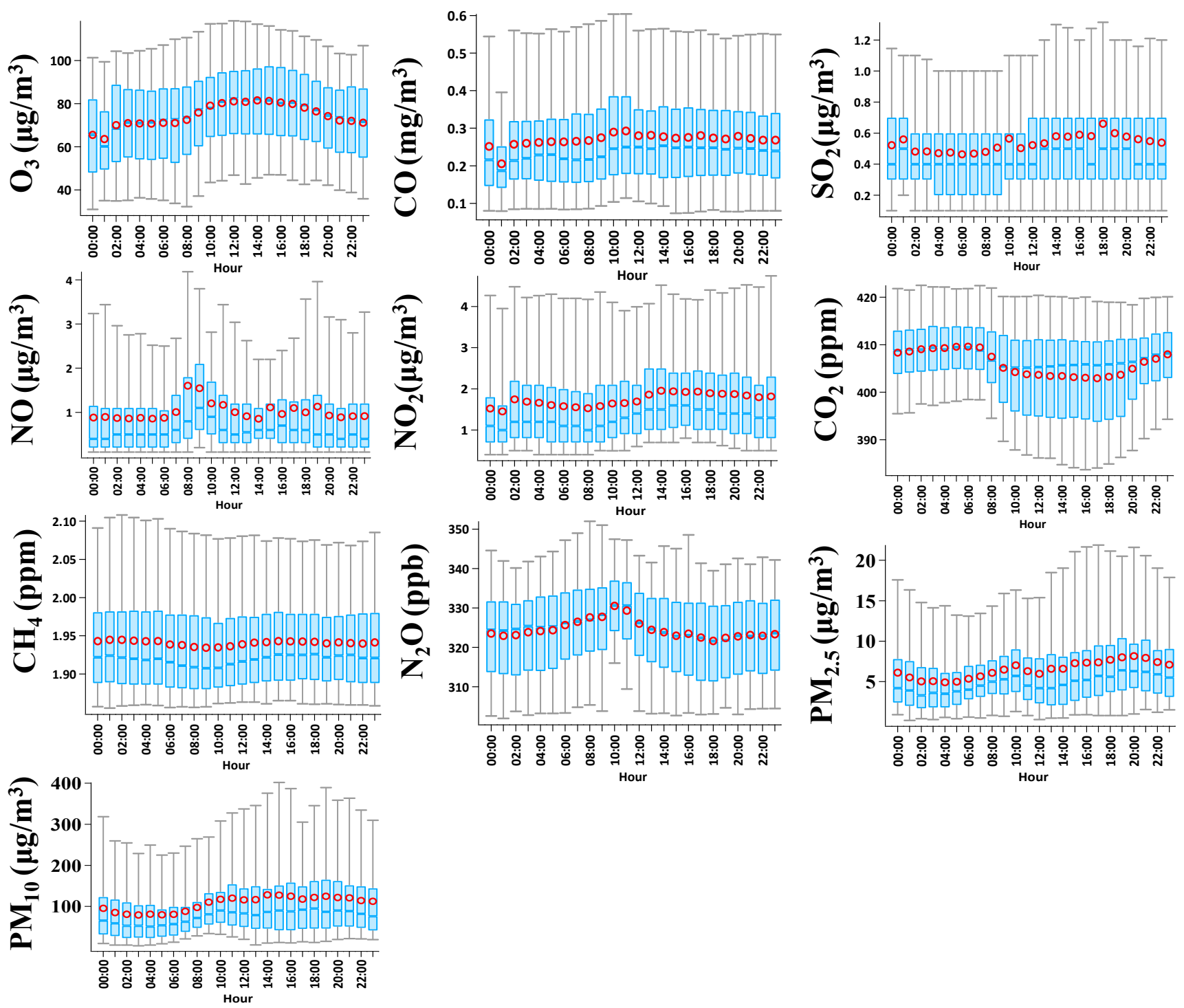

(a)
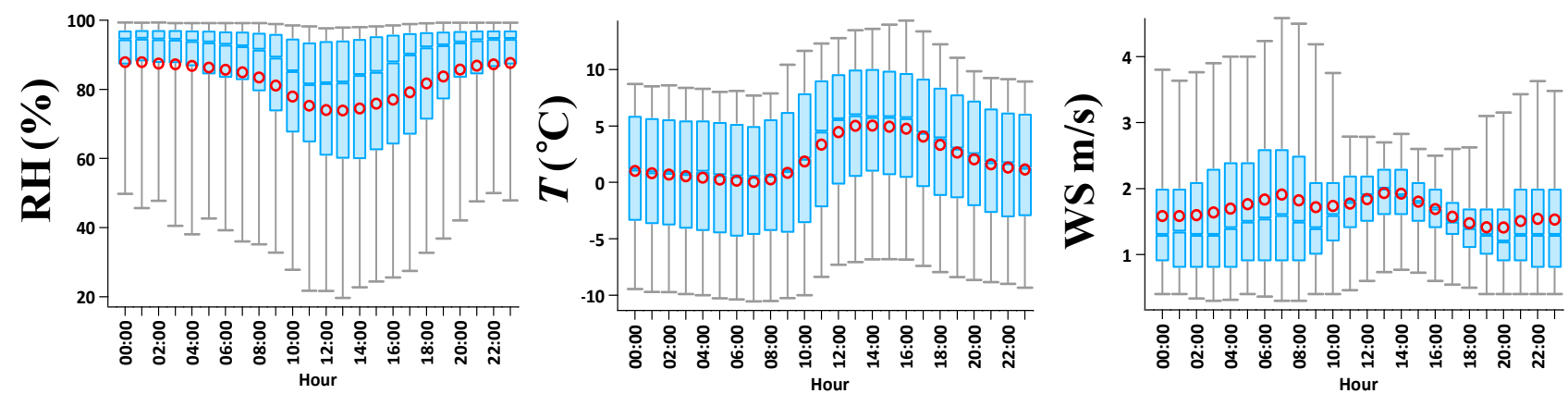

(b)

Fig. 5. Average diurnal variations in $\mathrm{O}_{3}, \mathrm{CO}, \mathrm{SO}_{2}, \mathrm{NO}_{x}, \mathrm{CO}_{2}, \mathrm{CH}_{4}, \mathrm{~N}_{2} \mathrm{O}, \mathrm{PM}_{2.5}$ and $\mathrm{PM}_{10}$ concentrations or mixing ratios (a) as well as RH, T and WS; (b) at the GGS station. 
deposition processes (Seinfeld and Pandis, 2016); during the daytime, with the increase in solar radiation after sunrise, $\mathrm{O}_{3}$ started increasing as more ozone was generated by photochemical reactions (Seinfeld and Pandis, 2016). Note that the daily amplitude of $\mathrm{O}_{3}$ at the background site was lower than that at urban sites (Reddy et al., 2011). The diurnal variations in $\mathrm{CO}$ and $\mathrm{NO}_{2}$ resulted in higher concentrations in the daytime and lower concentrations in the nighttime. The diurnal variations in $\mathrm{NO}$ and $\mathrm{N}_{2} \mathrm{O}$ resulted in obvious peaks at approximately 09:00 and 10:00, respectively. No obvious diurnal variation in $\mathrm{SO}_{2}$ was observed. The diurnal variations in $\mathrm{CO}$ and $\mathrm{NO}_{2}$ might be ascribed to two reasons. One reason could be that increasing anthropogenic activities in the daytime around the study site enhanced the primary emissions of these gases. The other reason may possibly be related to the evolution of the planetary boundary layer (PBL) and the transboundary transport of air pollutants. It is known that $\mathrm{CO}$ and $\mathrm{NO}_{2}$ concentrations increase with the decay of the nocturnal boundary layer, consequently making the high concentrations of these pollutants over source areas migrate to downwind receptor sites and leading to enhancements in $\mathrm{CO}$ and $\mathrm{NO}_{2}$ concentrations at the receptor sites during the daytime. The $\mathrm{PM}_{2.5}$ and $\mathrm{PM}_{10}$ concentrations did not show the obvious bimodal distribution that they show at urban sites (Wang et al., 2015). Similar to $\mathrm{CO}$ and $\mathrm{NO}_{2}$, a slight increase in the $\mathrm{PM}_{2.5}$ and $\mathrm{PM}_{10}$ concentrations was recorded in the daytime. Although the GGS is a regional background site, scattered anthropogenic emissions in the daytime could partly lead to the increase in the $\mathrm{PM}_{2.5}$ and $\mathrm{PM}_{10}$ concentrations; in addition, secondary aerosol formation via the atmospheric transformation of precursors from local sources or regional transport might contribute to higher concentrations of $\mathrm{PM}_{2.5}$ and $\mathrm{PM}_{10}$ during the daytime than during the nighttime.

The average diurnal variation in $\mathrm{CO}_{2}$ is shown in Fig. 5. The diurnal cycle of $\mathrm{CO}_{2}$ reflects a diurnal periodicity of atmospheric vertical mixing, the release and uptake of $\mathrm{CO}_{2}$ by respiration, photosynthesis in the biosphere and human activities. In the daytime, photosynthesis is dominant in the net exchange between the biosphere and atmosphere, which could lead to the decline in $\mathrm{CO}_{2}$ concentrations. During the nighttime, photosynthesis stops and vertical mixing is weak, while plant respiration continues. The $\mathrm{CO}_{2}$ emitted by plant respiration accumulates near the ground. In addition, anthropogenic emissions also contributed slightly to the observed $\mathrm{CO}_{2}$, although the GGS site was distant from densely populated areas. The $\mathrm{CH}_{4}$ mixing ratios showed a very weak diurnal variation, with minima during midday, which might be caused by the elevated $\mathrm{PBL}$, as anthropogenic emissions of $\mathrm{CH}_{4}$ are scarce in such a remote mountain area. $\mathrm{N}_{2} \mathrm{O}$ peaked at 10:00-12:00 and remained almost stable over the other time period. The $\mathrm{N}_{2} \mathrm{O}$ peak can probably be attributed to $\mathrm{N}_{2} \mathrm{O}$ emissions caused by enhanced microbial activity with the increase in soil temperatures. With the increase in solar radiation in the daytime, the soil temperature did not immediately increase with the atmospheric temperature due to the different heat capacities of the soil and atmosphere. With the increase in the soil temperature (generally $2 \mathrm{~h}$ later than that in the atmospheric temperature), the enhancement of microbial activity led to $\mathrm{N}_{2} \mathrm{O}$ peaks. In addition, $\mathrm{N}_{2} \mathrm{O}$ peaks did not occur with NO peaks, suggesting that they did not come from the same sources, i.e., vehicular emissions (Vojtíšek-Lom et al., 2018).

\section{Impacts of Transboundary Air Pollution and Local Emissions}

The impact of the regional transport and local emissions of air pollutants and greenhouse gases can be visualized based on both polar plots of wind and occurrence levels of the abovementioned pollutants as well as PSCF results of the hourly resolved input data. Fig. 6 shows the dependent distributions between WS/WD and the concentrations of all pollutants of interest. The concentrations of air pollutants and greenhouse gases showed evident wind sector gradients. For example, higher $\mathrm{O}_{3}, \mathrm{SO}_{2}$ and $\mathrm{PM}_{2.5}$ concentrations were correlated with winds from the northeast (NE), and lower concentrations were correlated with northwest (NW) winds. This wind sector dependence of $\mathrm{O}_{3}, \mathrm{SO}_{2}$ and $\mathrm{PM}_{2.5}$ concentrations is highly consistent with the spatial distribution of their concentrations in the surrounding areas. It was reported that relatively high and low $\mathrm{O}_{3}, \mathrm{SO}_{2}$ and $\mathrm{PM}_{2.5}$ concentrations were observed in the Cheng-Yu region and Tibetan Plateau, located to the northeast and northwest of the study site, respectively (China Environmental Statement, 2016). Clearly, zones with high concentrations of $\mathrm{NO}_{2}$, $\mathrm{CO}, \mathrm{CO}_{2}$ and $\mathrm{CH}_{4}$ were in the center of these dependent distribution areas where low WS was recorded, indicating that local emissions might play an important role in the accumulation of these air pollutants. In contrast to other air pollutants, higher $\mathrm{PM}_{10}$ concentrations were more correlated with high WS, although $\mathrm{PM}_{2.5}$ concentrations did not vary as much as the $\mathrm{PM}_{10}$. This result suggests that wind-blown sand or dust contributed significantly to $\mathrm{PM}_{10}$. In addition, winds from the southeast resulted in relatively high $\mathrm{PM}_{10}$ concentrations, possibly implying that mid- and/or longrange transport of aerosols from both the south and southeast could contribute to $\mathrm{PM}_{10}$.

Fig. 7 shows potential source areas for $\mathrm{O}_{3}, \mathrm{CO}, \mathrm{SO}_{2}$, $\mathrm{NO}_{2}, \mathrm{PM}_{2.5}$ and $\mathrm{PM}_{10}$ concentrations as well as the $\mathrm{CO}_{2}$, $\mathrm{CH}_{4}$ and $\mathrm{N}_{2} \mathrm{O}$ mixing ratios during the study period. As shown in Fig. 7, the potential source areas of air pollutants and greenhouse gases showed obvious spatial distributions. It appeared that parts of Inner Mongolia and Gansu, Ningxia, Sichuan, Chongqing and Hubei Provinces as well as adjacent areas of Hunan, Guizhou and Guangxi Provinces were potential source areas for $\mathrm{O}_{3}$, which is consistent with the link between WD and relatively high $\mathrm{O}_{3}$ concentrations. With the rapid economic development in inland areas of China, more intensive emissions of $\mathrm{O}_{3}$ precursors could lead to $\mathrm{O}_{3}$ formation during transport processes (China Environmental Statement, 2016). The potential source areas for $\mathrm{CO}$ were mainly focused on neighboring countries in South Asia, such as India and Pakistan, which were associated with high pollution emissions (https://nar.ucar.edu/ sites/default/files/labs/nes1/ACD-EmissionsParticulates02.jpg), in addition to areas of Inner Mongolia and Gansu and 

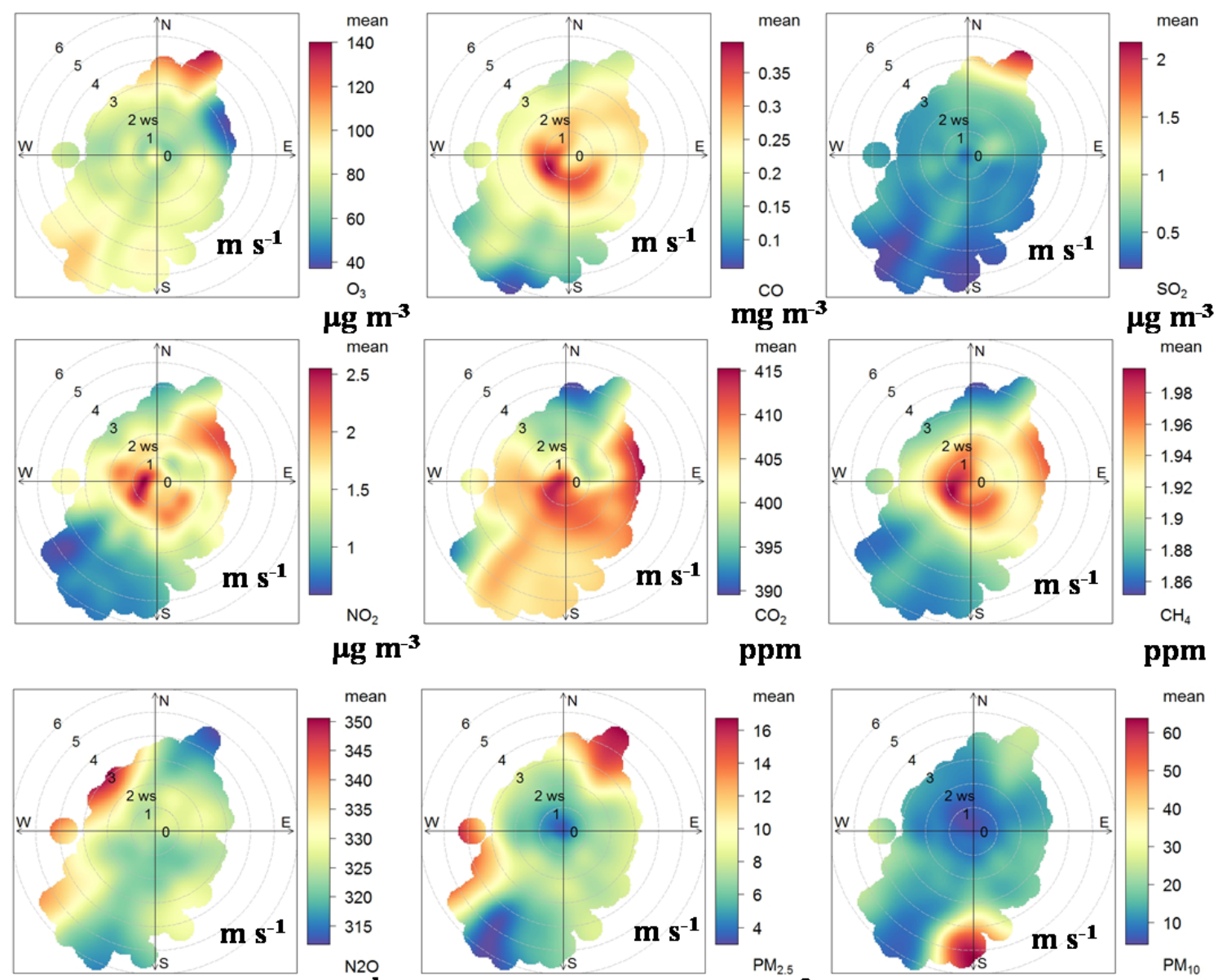

ppb

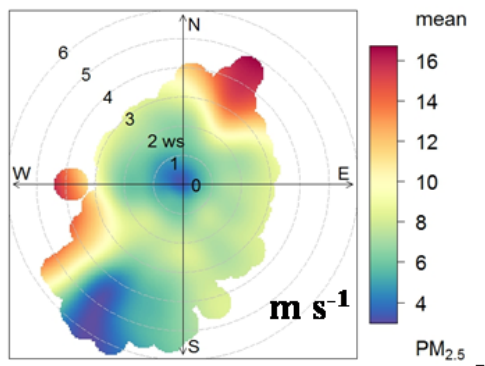

$\mu \mathbf{g ~ m}^{-3}$

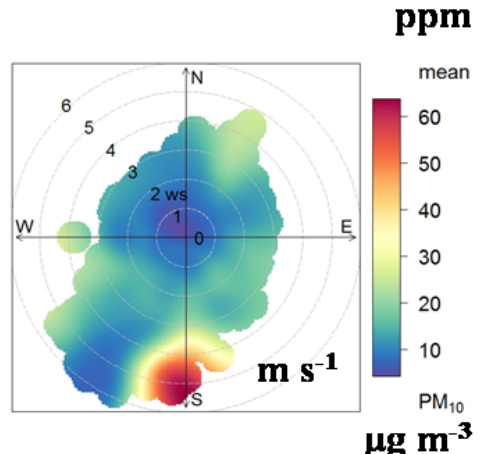

Fig. 6. The dependent distributions between wind speed and direction and the concentrations of $\mathrm{O}_{3}, \mathrm{CO}, \mathrm{SO}_{2}, \mathrm{NO}_{x}, \mathrm{CO}_{2}$, $\mathrm{CH}_{4}, \mathrm{~N}_{2} \mathrm{O}, \mathrm{PM}_{2.5}$ and $\mathrm{PM}_{10}$ at the GGS station.

Guizhou Provinces. Considering that $\mathrm{SO}_{2}$ has similar emission sources as $\mathrm{CO}$, the potential source areas for $\mathrm{SO}_{2}$ overlapped with those of $\mathrm{CO}$, but an intense $\mathrm{SO}_{2}$ band caused by the emissions of power plants appeared in parts of Inner Mongolia and Gansu Province (Liu et al., 2015). The potential source areas for $\mathrm{NO}_{2}, \mathrm{PM}_{2.5}$ and $\mathrm{PM}_{10}$ were also found in neighboring countries in South Asia in addition to Inner Mongolia, Gansu Province and the Cheng-Yu economic region. High emissions of air pollutants in the abovementioned areas may result in the increase in $\mathrm{NO}_{2}, \mathrm{PM}_{2.5}$ and $\mathrm{PM}_{10}$ concentrations at the GGS site via transboundary transport. This result is almost consistent with that obtained by $\mathrm{Qu}$ et al. (2008), who found that anthropogenic sources in the Cheng-Yu economic region (Sichuan Basin), southeastern Yunnan Province and South Asian countries evidently influence Zhuzhang (in a mountainous rural area of southwestern China, $3583 \mathrm{~m}$ a.s.1.). For $\mathrm{CO}_{2}$, the potential source areas were focused on South Asian countries neighboring China and the adjacent areas of the Tibet Autonomous Region, Yunnan Province and Myanmar, which could be caused by high fuel consumption resulting in high $\mathrm{CO}_{2}$ emissions (http://edgar.jrc.ec.europa.eu/overview.php? $\mathrm{v}=\mathrm{CO} 2$ andGH G1970-2016). The potential source areas of $\mathrm{CH}_{4}$ were mainly distributed in Myanmar, India and Pakistan and parts of Yunnan Province, China. The potential source areas of $\mathrm{N}_{2} \mathrm{O}$ were recorded in the Cheng-Yu economic region, Yunnan Province, borders of the Tibet Autonomous Region of China and countries of South Asia; it is understandable that these areas with intense agricultural activities are the main sources of $\mathrm{N}_{2} \mathrm{O}$ and $\mathrm{CH}_{4}$ (Davidson and Kanter, 2014; Saunois et al., 2016).

\section{CONCLUSION}

This report presents the first year-long (from January 1 to December 31, 2017) and real-time measurement study of $\mathrm{O}_{3}, \mathrm{NO}_{\mathrm{x}}, \mathrm{SO}_{2}, \mathrm{CO}, \mathrm{CO}_{2}, \mathrm{CH}_{4}, \mathrm{~N}_{2} \mathrm{O}, \mathrm{PM}_{2.5}$ and $\mathrm{PM}_{10}$ performed at the GGS background site in southwestern China. The frequency of occurrence and temporal variations of this pollution were discussed in detail, and potential contribution areas of the above substances were identified using PSCF. The conclusions of this study are as follows.

High $\mathrm{O}_{3}$ and $\mathrm{PM}_{2.5}$ concentrations that exceeded WHO thresholds were observed and were closely associated with the yield from $\mathrm{CO}$ oxidation and long-range transport and/or local emissions of PM. The $\mathrm{O}_{3}, \mathrm{CO}, \mathrm{SO}_{2}, \mathrm{NO}_{\mathrm{x}}$, 

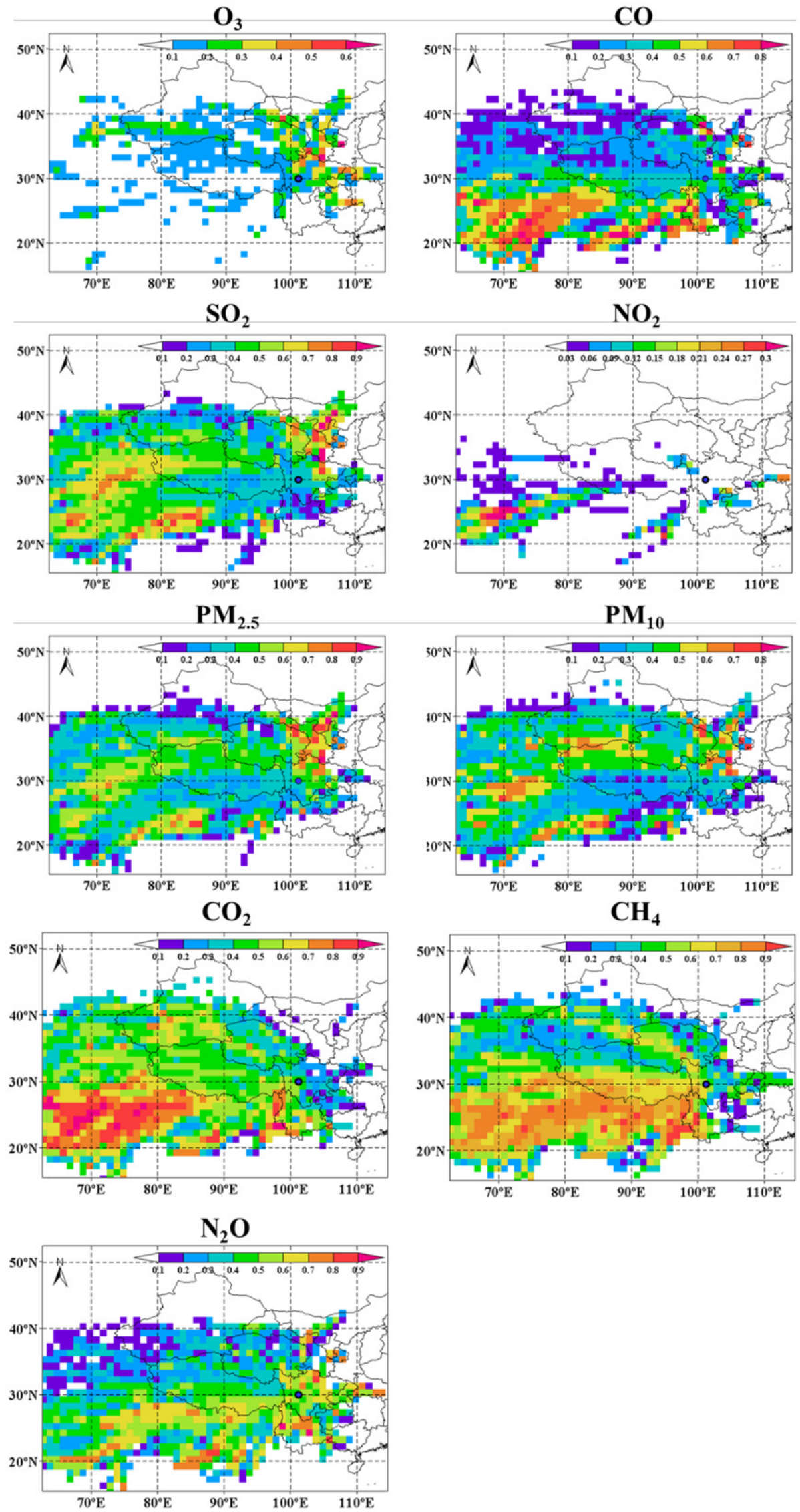

Fig. 7. Potential source areas for $\mathrm{O}_{3}, \mathrm{CO}, \mathrm{SO}_{2}, \mathrm{NO}_{2}, \mathrm{PM}_{2.5}$ and $\mathrm{PM}_{10}$ concentrations as well as $\mathrm{CO}_{2}, \mathrm{CH}_{4}$ and $\mathrm{N}_{2} \mathrm{O}$ mixing ratios during the study period. The color code denotes the PSCF probability. The location of the site is indicated by 
$\mathrm{CO}_{2}, \mathrm{CH}_{4}, \mathrm{~N}_{2} \mathrm{O}, \mathrm{PM}_{2.5}$ and $\mathrm{PM}_{10}$ concentrations presented typical lognormal patterns during the entire study period. The concentrations of these air pollutants at the GGS site were comparable to those at most background sites around the world. The slight differences in the levels of major air pollutants and greenhouse gases between background sites may be affected, to different extents, by anthropogenic emissions.

Obvious seasonal and diurnal variations were observed in the concentrations of $\mathrm{O}_{3}, \mathrm{CO}, \mathrm{NO}_{\mathrm{x}}, \mathrm{SO}_{2}, \mathrm{CO}_{2}, \mathrm{CH}_{4}$, $\mathrm{N}_{2} \mathrm{O}, \mathrm{PM}_{2.5}$ and $\mathrm{PM}_{10}$. High values were observed for $\mathrm{O}_{3}$ in spring and summer, and the diurnal variations were characterized by higher daytime than nighttime values. $\mathrm{SO}_{2}$ and $\mathrm{PM}_{2.5}$ reached their highest concentrations in summer and their lowest concentrations in autumn. Relatively high $\mathrm{CO}, \mathrm{NO}_{2}$ and $\mathrm{PM}_{10}$ concentrations were mostly observed in spring and winter. $\mathrm{CO}$ and $\mathrm{NO}_{2}$ exhibited higher concentrations in the daytime than in the nighttime. The vigorous summertime photosynthesis of vegetation resulted in lower $\mathrm{CO}_{2}$ concentrations during summer than during the other seasons. The lowest concentrations for $\mathrm{CH}_{4}$ were recorded in summer, whereas its levels in the other three seasons were similar to each other. High temperatures enhanced microbial activity, resulting in higher $\mathrm{N}_{2} \mathrm{O}$ concentrations during summer (compared to the other seasons) and in the daytime (compared to the nighttime).

Meteorological conditions significantly affect the background concentrations of the studied air pollutants. These pollutants can accumulate because of stagnant meteorological conditions and/or the contribution of midand long-range transport. The potential source areas for the air pollutants and greenhouse gases showed an obvious spatial distribution. The high potential source areas were distributed in parts of Inner Mongolia and Gansu, Ningxia, Sichuan, Chongqing and Hubei Provinces as well as adjacent areas of Hunan, Guizhou and Guangxi Provinces. High emissions in India and Pakistan also played an important role in increasing the $\mathrm{CO}, \mathrm{SO}_{2}, \mathrm{NO}_{2}, \mathrm{PM}_{2.5}$ and $\mathrm{PM}_{10}$ concentrations. In addition, anthropogenic emissions from Inner Mongolia and Gansu Province contributed greatly to the enhancement of $\mathrm{CO}, \mathrm{SO}_{2}, \mathrm{PM}_{2.5}$ and $\mathrm{PM}_{10}$. Increases in the $\mathrm{CO}_{2}$ concentration due to high fuel consumption were traceable primarily to South Asian countries neighboring China, and the adjacent areas of the Tibet Autonomous Region, Yunnan Province and Myanmar, whereas the enhancement of $\mathrm{CH}_{4}$ and $\mathrm{N}_{2} \mathrm{O}$ concentrations in the Cheng-Yu economic region, Yunnan Province, the Tibet Autonomous Region of China, Myanmar, India and Pakistan were attributable to intense agricultural activities.

The results of this study contribute to a better understanding of how anthropogenic activities impact the occurrence of air pollution against regional backgrounds, which may improve the modeling of regional air quality in the future.

\section{ACKNOWLEDGEMENTS}

This work was supported by the Beijing Municipal Science and Technology Project (D17110900150000 and
Z171100000617002), CAS Key Technology Talent Program and National Research Program for Key Issues in Air Pollution Control (DQGG0101). The authors would like to thank all members participating in the air quality campaign at the GGS background site.

\section{REFERENCES}

Bian, L.G., Gao, Z.Q., Sun, Y.L., Ding, M.H., Tang, J. and Schnell, R. (2016). $\mathrm{CH}_{4}$ monitoring and background concentration at Zhongshan Station. Atmos. Clim. Sci. 6: 135-144.

Chao, N., Ji, D.S., Chen, J.S., Xin, J.Y., Hu, B., Wang, Y.S. and Wang, H. (2014). Characteristics of gaseous pollutants at a regional background station in Southern China. Atmos. Ocean Sci. Lett. 7: 340-345.

China Environmental Statement (2016). http:/www.zhb. gov.cn/hjzl/zghjzkgb/lnzghjzkgb/201706/P02017060583 3655914077.pdf.

Christiansen, J.R., Outhwaite, J. and Smukler, S.M. (2015). Comparison of $\mathrm{CO}_{2}, \mathrm{CH}_{4}$ and $\mathrm{N}_{2} \mathrm{O}$ soil-atmosphere exchange measured in static chambers with cavity ringdown spectroscopy and gas chromatography. Agric. For. Meteorol. 211: 48-57.

Cortus, E.L., Jacobson, L.D., Hetchler, B.P., Heber, A.J. and Bogan, B.W. (2015). Methane and nitrous oxide analyzer comparison and emissions from dairy freestall barns with manure flushing and scraping. Atmos. Environ. 100: 57-65.

Cristofanelli, P., Bracci, A., Sprenger, M., Marinoni, A., Bonafè, U., Calzolari, F., Duchi, R., Laj, P., Pichon, J.M., Roccato, F., Venzac, H., Vuillermoz, E. and Bonasoni, P. (2010). Tropospheric ozone variations at the Nepal climate observatory-pyramid (Himalayas, $5079 \mathrm{~m}$ a.s.1.) and influence of deep stratospheric intrusion events. Atmos. Chem. Phys. 10: 1483-1516.

Davidson, E.A. and Kanter, D. (2014). Inventories and scenarios of nitrous oxide emissions. Environ. Res. Lett. 9: 105012.

Escudero, M., Lozano, A., Hierro, J., Valle, J.D. and Mantilla, E. (2014). Urban influence on increasing ozone concentrations in a characteristic Mediterranean agglomeration. Atmos. Environ. 99: 322-332.

Fu, X., Feng, X., Zhu, W., Zheng, W., Wang, S. and Lu, J. Y. (2008). Total particulate and reactive gaseous mercury in ambient air on the eastern slope of the Mt. Gongga area, China. Appl. Geochem. 23: 408-418.

Gligorovski, S., Strekowski, R., Barbati, S. and Vione, D. (2015). Environmental implications of hydroxyl radicals $(\cdot \mathrm{OH})$. Chem. Rev. 115: 13051-13092.

IPCC (2001). Climate Change 2001: Synthesis report. http://www.grida.no/publications/267

Ji, D.S., Wang, Y.S. and Sun, Y. (2008). A comparative study on gaseous air pollutants in Beijing and London. Chinese J. Environ. Eng. 2: 1199-1206 (in Chinese with English Abstract).

Ji, D.S., Wang, Y.S., Wang, L.L., Chen, L., Hu, B. and Tang, G.Q. (2012). Analysis of heavy pollution episodes in selected cities of northern china. Atmos. Environ. 50: 
$338-348$.

Ji, D.S., Wang, L.L., Wang, Y.S., Zhang, J.K., Cheng, M.T. and Sun, Y. (2014). The heaviest particulate air-pollution episodes occurred in northern china in January, 2013: Insights gained from observation. Atmos. Environ. 92: 546-556.

Jia, L. and Xu, Y.F. (2014). Effects of relative humidity on ozone and secondary organic aerosol formation from the photooxidation of benzene and ethylbenzene. Aerosol Sci. Technol. 48: 1-12.

Jonsson, O., Andersson, C., Forsberg, B. and Johansson, C. (2013). Air pollution episodes in Stockholm regional background air due to sources in Europe and their effects on human population. Boreal Environ. Res. 18: 280-302.

Lam, K.S., Wang, T.J., Wang, T., Tang, J., Kajii, Y., Liu, C.M. and Shim, S.G. (2004). Overview of surface ozone variability in East Asia-North Pacific region during IGAC/APARE (1994-1996). J. Environ. Sci. 16: 599609.

Li, L., Lai, W., Pu, J., Mo, H., Dai, D., Wu, G. and Deng, S. (2017). Polar organic tracers in $\mathrm{PM}_{2.5}$ aerosols from an inland background area in Southwest China: Correlations between secondary organic aerosol tracers and source apportionment. J. Environ. Sci.-China 69: 281-293.

Lin, M., Horowitz, L.W., Oltmans, S.J., Fiore, A.M. and Fan, S. (2014). Tropospheric ozone trends at Mauna Loa Observatory tied to decadal climate variability. Nat. Geosci. 7: 136-143.

Lin, W., Xu, X. and Zhang, X.H. (2008). Contributions of pollutants from North China Plain to surface ozone at the Shangdianzi GAW Station. Atmos. Chem. Phys. 8: 5889-5898.

Lin, W., Xu, X. and Sun, J. (2011). Characteristics of gaseous pollutants at Jinsha, a remote mountain site in Central China. Sci. China Ser. B 41: 136-144.

Lin, W., Xu, X., Zheng, X., Dawa, J., Baima, C. and Ma, J. (2015). Two year measurements of surface ozone at Dangxiong, a remote highland site in the Tibetan Plateau. J. Environ. Sci. 31: 133-145.

Liu, F., Zhang, Q., Tong, D., Zheng, B., Li, M., Huo, H. and He, K.B. (2015). High-resolution inventory of technologies, activities, and emissions of coal-fired power plants in China from 1990 to 2010. Atmos. Chem. Phys. 15: 13299-1331.

Liu, H., Hu, B., Wang, Y.S., Liu, G.R., Tang, L.Q., Ji, D.S., Bai, Y.F., Bao, W.K., Chen, X., Chen, Y. M., Ding, W.X., Han, X.Z., He, F., Huang, H., Huang, Z.Y., Li, X.R., Li, Y., Liu, W.Z., Lin, L.X., Ouyang, Z., Qin, B.Q., Shen, W.J., Shen, Y.J., Su, H.X., Song, C.C., Sun, B., Sun, S., Wang, A.Z., Wang, G.X., Wang, H.M., Wang, S.L., Wang, Y.S., Wei, W.X., Xie, P., Xie, Z.Q., Yan, X.Y., Zeng, F.J., Zhang, F.W., Zhang, Y.J., Zhang, Y.P., Zhao, C.Y., Zhao, W.Z., Zhao, X.Y., Zhou, G.Y. and Zhu, B. (2017). Two ultraviolet radiation datasets that cover China. Adv. Atmos. Sci. 34: 805-815.

Lupu, A. and Maenhaut, W. (2002). Application and comparison of two statistical trajectory techniques for identification of source regions of atmospheric aerosol species. Atmos. Environ. 36: 5607-5618.

Ma, J., Lin, W.L., Zheng, X.D., Xu, X.B., Li, Z. and Yang, L.L. (2014). Influence of air mass downward transport on the variability of surface ozone at Xianggelila Regional Atmosphere Background Station, southwest China. Atmos. Chem. Phys. 14: 5311-5325.

Mauzerall, D.L., Jacob, D.J., Fan, S.M., Bradshaw, J.D., Gregory, G.L. and Sachse, G.W. (1996). Origin of tropospheric ozone at remote high northern latitudes in summer. J. Geophys. Res. 101: 4175-4188.

Meng, Z., Zhang, R., Lin, W., Jia, X., Yu, X., Yu, X. and Wang, G. (2014). Seasonal variation of ammonia and ammonium aerosol at a background station in the Yangtze River Delta region, China. Aerosol Air Qual. Res. 14: 756-766.

Monks, P.S. (2000). A review of the observations and origins of the spring ozone maximum. Atmos. Environ. 34: 3545-3561.

Monks, P.S., Archibald, A.T., Colette, A., Cooper, O., Coyle, M., Derwent, R., Fowler, D., Granier, C., Law, K.S., Mills, G.E., Stevenson, D.S., Tarasova, O., Thouret, V., Von Schneidemesser, E., Sommariva, R., Wild, O. and Williams, M.L. (2015). Tropospheric ozone and its precursors from the urban to the global scale from air quality to short-lived climate forcer. Atmos. Chem. Phys. 15: 8889-8973.

National Bureau of Statistics of the People's Republic of China (2017). http://www.stats.gov.cn/english/

Necki, J., Schmidt, M., Rozanski, K., Zimnoch, M., Korus, A., Lasa, J., Graul, R. and Levin, I. (2003). Six-year record of atmospheric carbon dioxide and methane at a high-altitude mountain site in Poland. Tellus B 55: 94 104.

Orru, H., Ebi, K.L. and Forsberg, B. (2017). The interplay of climate change and air pollution on health. Curr. Environ. Health Rep. 4: 504-513.

Pu, W.W., Shi, X.F., Ma, Z.Q., Zhao, X.J., Zhang, X.L. and $\mathrm{Xu}$, X.F. (2015). Impact of atmospheric pollutants transport pathways on aerosol optical properties at Shangdianzi background station. Environ. Sci. 36: 379 387 (in Chinese with English Abstract).

Qu, W.J., Zhang, X.Y., Arimoto, R., Wang, D., Wang, Y. Q., Yan, L.W. and Li, Y. (2008). Chemical composition of the background aerosol at two sites in southwestern and northwestern China: Potential influences of regional transport. Tellus B 60: 657-673.

Qu, W.J., Zhang, X.Y., Arimoto, R., Wang, Y.Q., Wang, D., Sheng, L.F. and Fu, G. (2009). Aerosol background at two remote CAWNET sites in western China. Sci. Total Environ. 407: 3518-3529.

Ran, L., Lin, W.L., Deji, Y.Z., La, B., Tsering, P.M., Xu, X.B. and Wang, W. (2014). Surface gas pollutants in Lhasa, a highland city of Tibet - current levels and pollution implications. Atmos. Chem. Phys. 14: 1072110730.

Reddy, B.S.K., Reddy, L.S.S., Cao, J.J., Kumar, K.R., Balakrishnaiah, G., Gopal, K.R., Reddy, R.R., Narasimhulu, K., Lal, S. and Ahammed, Y.N. (2011). 
Simultaneous measurements of surface ozone at two sites over the Southern Asia: A comparative study. Aerosol Air Qual. Res. 11: 895-902.

Saunois, M., Bousquet, P., Poulter, B., Peregon, A., Ciais, P., Canadell, J.G., Dlugokencky, E.J., Etiope, G., Bastviken, D., Houweling, S., Janssens-Maenhout, G., Tubiello, F.N., Castaldi, S., Jackson, R.B., Alexe, M., Arora, V.K., Beerling, D.J., Bergamaschi, P., Blake, D.R., Brailsford, G., Brovkin, V., Bruhwiler, L., Crevoisier, C., Crill, P., Covey, K., Curry, C., Frankenberg, C., Gedney, N., Höglund-Isaksson, L., Ishizawa, M., Ito, A., Joos, F., Kim, H.S., Kleinen, T., Krummel, P., Lamarque, J.F., Langenfelds, R., Locatelli, R., Machida, T., Maksyutov, S., McDonald, K.C., Marshall, J., Melton, J.R., Morino, I., Naik, V., O'Doherty, S., Parmentier, F.J.W., Patra, P.K., Peng, C., Peng, S., Peters, G.P., Pison, I., Prigent, C., Prinn, R., Ramonet, M., Riley, W.J., Saito, M., Santini, M., Schroeder, R., Simpson, I.J., Spahni, R., Steele, P., Takizawa, A., Thornton, B.F., Tian, H., Tohjima, Y., Viovy, N., Voulgarakis, A., van Weele, M., van der Werf, G.R., Weiss, R., Wiedinmyer, C., Wilton, D.J., Wiltshire, A., Worthy, D., Wunch, D., Xu, X., Yoshida, Y., Zhang, B., Zhang, Z. and Zhu, Q. (2016). The global methane budget 2000-2012. Earth Syst. Sci. Data 8: 697-751.

Seinfeld, J.H. and Pandis, S.N. (2016). Atmospheric chemistry and physics: From air pollution to climate change. John Wiley \& Sons, New York.

Sun, L., Xue, L., Wang, T., Gao, J., Ding, A., Cooper, O.R., Lin, M.Y., Xu, P.J., Wang, Z., Wang, X.F., Wen, L., Zhu, Y.H., Chen, T.S., Yang, L.X., Wang Y., Chen, J.M. and Wang, W.X. (2016). Significant increase of summertime ozone at Mt. Tai in central eastern China: 2003-2015. Atmos. Chem. Phys. 16: 10637-10650.

Thunis, P., Miranda, A., Baldasano, J.M., Blond, N., Douros, J., Graff, A., Janssen, S., Juda-Rezler, K., Karvosenoja, N., Maffeis, G., Martilli, A., Rasoloharimahefa, M., Real, E., Viaene, P., Volta, M. and White, L. (2016). Overview of current regional and local scale air quality modelling practices: Assessment and planning tools in the EU. Environ. Sci. Policy 65: 13-21.

Vingarzan, R. (2004). A review of surface ozone background levels and trends. Atmos. Environ. 38: 3431-3442.

Vojtíšek-Lom, M., Beránek, V., Klír, V., Jindra, P., Pechout, M. and Voř́rššk, T. (2018). On-road and laboratory emissions of $\mathrm{NO}, \mathrm{NO}_{2}, \mathrm{NH}_{3}, \mathrm{~N}_{2} \mathrm{O}$ and $\mathrm{CH}_{4}$ from latemodel EU light utility vehicles: Comparison of diesel and CNG. Sci. Total Environ. 616: 774-784.

Wang, B., Li, J., Wan, Y., Li, Y.E., Qin, X., Gao, Q., Waqas, M.A., Wilkes, A., Cai, W., You, S. and Zhou, S. (2018). Responses of yield, $\mathrm{CH}_{4}$ and $\mathrm{N}_{2} \mathrm{O}$ emissions to elevated atmospheric temperature and $\mathrm{CO}_{2}$ concentration in a double rice cropping system. Eur. J. Agron. 96: 60-69.

Wang, H., Zhu, B., Shen, L., Xu, H., An, J., Pan, C. and Liu, D. (2016). Regional characteristics of air pollutants during heavy haze events in the Yangtze River Delta, China. Aerosol Air Qual. Res. 16: 2159-2171.

Wang, Y.Q., Zhang, X.Y. and Draxler, R.R. (2009). TrajStat: GIS-based software that uses various trajectory statistical analysis methods to identify potential sources from long-term air pollution measurement data. Environ. Modell. Software 24: 938-939.

Wang, Y.Q., Zhang, X.Y., Sun, J.Y., Zhang, X.C., Che, H.Z. and Li, Y. (2015). Spatial and temporal variations of the concentrations of $\mathrm{PM}_{10}, \mathrm{PM}_{2.5}$ and $\mathrm{PM}_{1}$ in China. Atmos. Chem. Phys. 15: 13585-13598.

Watson, R.T., Meira Filho, L.G., Sanhueza, E. and Janetos, A. (1992). Greenhouse gases: Sources and sinks. Clim. Change 92: 25-46.

Weinhold, B. (2008). Ozone nation: EPA standard panned by the people. Environ. Health Perspect. 116: A302A305.

Wu, C., Wu, D. and Yu, J.Z. (2018). Quantifying black carbon light absorption enhancement with a novel statistical approach. Atmos. Chem. Phys. 18: 289-309.

Wuebbles, D.J., Fahey, D.W., Hibbard, K.A., DeAngelo, B., Doherty, S., Hayhoe, K., Horton, R., Kossin, J.P., Taylor, P.C., Waple, A.M. and Weaver, C.P. (2017). Executive summary. In Climate science special report: Fourth national climate assessment, Volume I, Wuebbles, D.J., Fahey, D.W., Hibbard, K.A., Dokken, D.J., Stewart, B.C. and Maycock, T.K. (Eds.), U.S. Global Change Research Program, Washington, DC, USA, pp. 12-34, http://science2017.globalchange.gov/

Xu, W.Y., Lin, W.L., Xu, X.B., Tang, J., Huang, J.Q., Wu, H. and Zhang, X.C. (2016). Long-term trends of surface ozone and its influencing factors at the Mt Waliguan GAW station, China-Part 1: Overall trends and characteristics. Atmos. Chem. Phys. 16: 6191-6205.

Xu, W.Y., Xu, X.B., Lin, M.Y., Lin, W.L., Tarasick, D., Tang, J., Ma, J.Z. and Zheng, X.D. (2018). Long-term trends of surface ozone and its influencing factors at the Mt. Waliguan GAW station, China-Part 2: The roles of anthropogenic emissions and climate variability. Atmos. Chem. Phys. 18: 773-798.

Xu, X., Lin, W., Wang, T., Yan, P., Tang, J., Meng, Z. and Wang, Y. (2008). Long-term trend of surface ozone at a regional background station in eastern China 1991-2006: Enhanced variability. Atmos. Chem. Phys. 8: 2595-2607.

Ye, W.J., Bian, L.J., Wang, C., Zhu, R.B., Zheng, X.D. and Ding, M.H. (2016). Monitoring atmospheric nitrous oxide background concentrations at Zhongshan Station, east Antarctica. J Environ. Sci. 47: 193-200.

Zhang, J., Sun, Y., Wu, F., Sun, J. and Wang, Y. (2014). The characteristics, seasonal variation and source apportionment of VOCs at Gongga Mountain, China. Atmos. Environ. 88: 297-305.

Zhang, N., Cao, J., Ho, K. and He, Y. (2012). Chemical characterization of aerosol collected at Mt. Yulong in wintertime on the southeastern Tibetan Plateau. Atmos. Res. 107: 76-85.

Received for review, November 3, 2018 Revised, December 13, 2018 Accepted, January 25, 2019 